\title{
Aux rendez-vous de la mondialisation
}

Pourquoi les professionnel-les du commerce international continuent de fréquenter les marchés audiovisuels internationaux

Meeting within Globalization. Why attend International Film and Television Marketplaces

Presentes a las citas de la globalización. Por qué frecuentar los mercados audiovisuales internacionales

\section{Romain Lecler}

\section{(2) OpenEdition}

\section{Journals}

Édition électronique

URL : http://journals.openedition.org/bssg/398

DOI : $10.4000 /$ bssg.398

ISSN : 2490-9424

Éditeur

Presses universitaires de Vincennes

Référence électronique

Romain Lecler, « Aux rendez-vous de la mondialisation », Biens Symboliques / Symbolic Goods [En

ligne], 6 | 2020, mis en ligne le 30 avril 2020, consulté le 04 mars 2021. URL : http://

journals.openedition.org/bssg/398; DOI : https://doi.org/10.4000/bssg.398 


\section{Aux rendez-vous de la mondialisation}

\section{Pourquoi les professionnel-les du commerce international continuent de fréquenter les marchés audiovisuels internationaux}

\section{Meeting within Globalization}

Why attend International Film and Television Marketplaces

Romain Lecler

traduction | translation

Alba Simaku

\begin{abstract}
Alors que les professionnel-le-s du commerce international peuvent de plus en plus échanger à distance, en communicant par téléphone et par Internet, les événements internationaux lors desquels ils et elles se rencontrent ont persisté, et se sont même multipliés et agrandis depuis les années 1980. Or ces événements - les salons, foires et marchés internationaux - constituent un terrain d'observation privilégié de la mondialisation (Brailly \& Favre 2016) dans la mesure où celle-ci désigne un essor inédit du commerce international et des échanges transnationaux (Lecler 2013, 2018). Ils héritent à la fois des foires et marchés préindustriels (Dollfus 1982 ; Fontaine 2013 : 55 ; Margairaz 1988) et des expositions universelles ou des salons industriels et technologiques des $\mathrm{XIX}^{\mathrm{e}}$ et xx $x^{e}$ siècles (Benjamin 1997 ; Gunning 1994 : 423 ; Weber 2015). On en recense aujourd'hui 10000 dans 1000 villes environ à travers le monde. Ils vont de l'aéronautique (179 événements) au luxe (51) en passant par l'emballage (262) ou l'érotisme (33) ${ }^{1}$.
\end{abstract}

Although it is increasingly possible for international business professionals to communicate from a distance-on the phone or online-international events at which professionals meet in person have paradoxically not only continued, but have multiplied and grown since the 1980s. These events-international trade fairs, trade shows, and marketplaces-are in fact an excellent field for observing globalization (Brailly \& Favre 2016) insofar as the latter refers to an unprecedented expansion of international business and transnational exchange (Lecler 2015a, 2018). They stem from both preindustrial trade fairs and international marketplaces (Dollfus 1982; Fontaine 2013: 55; Margairaz 1988), as well as universal exhibitions and industry and technology trade shows of the nineteenth and twentieth centuries (Benjamin 1999: 18; Gunning 1994: 423; Weber 2015). Ten thousand are listed today, in approximately a thousand cities around the world. They range from aeronautics (179 events) to luxury goods (51) via

1. Base de données Eventseye, 2014, calculs de l'auteur. 
Dans tous les secteurs, les professionnel-le·s des échanges internationaux fréquentent un " circuit » d'événements, comme dans le cas de la télévision ou du cinéma (Lecler 2017a). Dans la revue professionnelle Écran total, les journalistes spécialistes du secteur audiovisuel s'étonnaient par exemple, en 1999, de la forte expansion des marchés internationaux malgré la généralisation des communications à distance. Ils en concluaient que la mondialisation « ne fait que renforcer le besoin des individus de se rencontrer en chair et en os $^{2} »$.

Ce paradoxe ressemble à celui qui a fasciné les théoricien·ne·s de la mondialisation : la dispersion de la production à l'échelle mondiale parallèlement à la concentration des dirigeants, des élites et des experts dans des "villes globales » (Sassen 1996) ou des clusters (Castells 1998). Pour l'expliquer, un groupe de géographes définit ces marchés, foires et salons comme des " plateformes de création et de circulation du savoir » (Bathelt \& Schuldt 2010) pour accéder à des « savoirs éloignés 》 (Maskell 2014), ou comme des « clusters temporaires » propices à un «buzz mondial » riche en information (Schuldt \& Bathelt 2011), ou encore comme des " points nodaux » du commerce international (Skov 2006) et des « nœuds centraux de l'économie politique mondiale » (Schuldt \& Bathelt 2011) : à leurs yeux, ces événements permettent avant tout aux entreprises d'apprendre sur leurs concurrents, leurs partenaires (Maskell 2014 : 893) et leur secteur (Rinallo \& Golfetto 2011 ; Sharland \& Balogh 1996). Comme dans les « villes globales » ou les « clusters ", la concentration des individus et leur " coprésence » (Bathelt \& Schuldt 2008) favoriseraient surtout la collecte d'information.

2. Écran Total, « Édito », 13 octobre 1999. packaging (262) and eroticism (33) ${ }^{1}$. In all sectors, international exchange professionals attend an international event circuit, such as in television or cinema (Lecler, 2017a). For instance, in a 1999 article of the French professional magazine Écran total, journalists specializing in the media sector showed their surprise at the massive expansion of international marketplaces despite the widespread use of long-distance communication. They concluded that globalization "only reinforces the need for individuals to meet in person²."

This resembles another paradox that has fascinated globalization theorists: the dispersion of production on a global scale, while leaders, elites, and experts are concentrated in "global cities" (Sassen 1991) or "clusters" (Castells 1996). To illustrate this, a group of geographers defined these marketplaces, fairs, and shows as "platforms for the creation and circulation of knowledge" (Bathelt \& Schuldt 2010) to access "distant knowledge" (Maskell 2014); as "temporary clusters" facilitating an information-rich "worldwide buzz" (Schuldt \& Bathelt 2011); or as "nodes" in international business (Skov 2006) or "central nodes of the global political economy" (Schuldt \& Bathelt 2011). In fact, in their eyes, these events above all allow companies to learn about their competitors, partners (Maskell 2014: 893), and sector (Rinallo \& Golfetto 2011 Sharland \& Balogh 1996). As with "global cities" or "clusters," the concentration of individuals and their "co-presence" (Bathelt \& Schuldt 2008) are mainly supposed to facilitate data collection.

1. EventsEye database 2014 , calculations by the author.

2. Écran total, "Édito," 13 October 1999. 
Ces approches laissent cependant de côté une dimension cruciale du commerce international, qui est d'abord caractérisé par un problème de défiance, puisqu'il met aux prises des professionnel-le.s représentant des territoires dont les systèmes juridiques et professionnels, mais aussi la culture et les manières d'échanger, sont très différents. II renforce donc les risques de tromperie, d'escroquerie ou même de malentendus consubstantiels à l'échange marchand. Avec le développement du commerce international au $\mathrm{xx}^{\mathrm{e}}$ siècle, ce risque accru explique la mise en place de nombreux dispositifs de médiation, comme un droit du commerce international prudentiel, la lex mercatoria, des cours d'arbitrage international (Lemercier \& Sgard 2015) ou encore des agences nationales de couverture des risques à l'export (comme la Compagnie française d'assurance pour le commerce extérieur [Coface] ${ }^{3}$ ). Historiquement, ce risque avait été conjuré par les liens forts des réseaux familiaux, religieux ou ethniques, et par un système de réputations appuyé sur une même culture mercantile (Trivellato 2016). Puis, lors du « désencastrement social »du commerce à distance au XIX siècle, les "commis voyageurs" ont permis de " conférer à des relations entre fournisseur et client à tout point de vue "faibles", car anonymes et dépersonnalisées, la force de liens forts " (Lemercier, Bartolomei, Marzagalli 2012 : 21). Cette perspective historique invite donc à penser les salons, foires et marchés internationaux comme une nouvelle solution à ce problème de défiance. Ces événements, dans leurs caractéristiques actuelles (spécialisation, professionnalisation et systématisation), s'inventent en effet au début du $x x^{\mathrm{e}}$ siècle avec les « foires d'échantillon » (Debluë 2015).

3. La Compagnie française d'assurance pour le commerce extérieur est une société d'assurance-crédit fondée en 1946 et privatisée en 1994.
But these theories miss out on a crucial aspect of international trade, which is first characterized by a problem of mistrust, since professionals in the area are pitted against one another, insofar as their judiciary and professional judiciary and professional systems, cultures, and methods of exchange are very different. The risk of deceit, fraud, or even misunderstandings that are consubstantial with commodity exchange is thereby reinforced. The development of international trade in the twentieth century gave way to an increased risk, which explains the implementation of various mediation devices, such as a prudential international trade right, the lex mercatoria, international arbitration rates (Lemercier \& Sgard 2015), and even national export risk control agencies (such as COFACE $^{3}$ ). Historically, such risk was averted by strong ties through family, religious, or ethnic networks, and by a reputation system based on a shared commercial culture (Trivellato 2012). During the "social disembedding" of long-distance commerce in the nineteenth century, "commercial travelers" were able to "confer the strength of strong ties to buyer-seller relationships which, from all perspectives, seemed to be 'weak', since they were anonymous and depersonalized" (Lemercier, Bartolomei, Marzagalli 2012: 21). This historical perspective invites us to think of international trade shows, fairs, and marketplaces as a new solution to the issue of defiance. These events, in their current characteristics (specialization, professionalization, and systematization), were indeed invented at the beginning of the twentieth century with "sample trade fairs" (Debluë 2015).

3. The Compagnie française d'assurance pour le commerce extérieur is an insurance-credit agency founded in 1946 and privatized in 1994. 
De nombreux travaux de sociologie économique renseignent justement sur des marchés où la confiance ne va pas de soi (Dubuisson-Quellier \& Neuville $2003: 17$ ) et où les participant.e.s se tiennent « à distance les uns des autres » (Chantelat 2002 : 532). L'observation des marchés en Kabylie amène ainsi Bourdieu à constater : "Les rapports réduits à leur dimension purement "économique" sont conçus comme des rapports de guerre, qui ne peuvent s'engager qu'entre étrangers, et le lieu par excellence de la guerre économique est le marché. " II indique alors comment tout y est fait pour "substituer un rapport personnel à un rapport impersonnel et anonyme » (Bourdieu 2003 : 80). Bien des chercheuses et des chercheurs s'appuient ainsi sur l'observation des interactions marchandes pour montrer comment la confiance se construit en face à face, « sur le fil du rasoir » (Chantelat \& Vignal 2002), grâce à des " professionnels de l'interaction symbolique " (Le Velly 2007), ou comment elle implique un « recodage personnel des interactions » pour « flirter [...] avec le registre de la relation personnelle » (Weber $2000: 106-107$ ) et nécessite le recours à des « supports caractérisés de confiance » (Trompette 2009).

Ce type d'approche permet de montrer que les participant.e.s aux salons, foires et marchés internationaux cherchent beaucoup moins à y réaliser des transactions ou à y collecter de l'information économique qu'à intégrer une communauté professionnelle, à en assimiler les normes et in fine à " personnaliser » leurs échanges. C'est ce que révèle une enquête de terrain menée au début des années 2010 sur les deux principaux événements internationaux du secteur audiovisuel, tous deux situés à Cannes ${ }^{4}$. Les exportations mondiales de biens et services audiovisuels représentent alors

4. Signalons que la sociologie du festival de Cannes (Alexandre 2015, Esquerre 2012, Ethis 2001, Gimello-Mesplomb \& Latil 2003, Valck 2007) s'intéresse peu à son marché, et encore moins aux marchés de télévision où s'échangent de nombreux films (Lecler 2015, 2017a, 2017b)
Many studies in economic sociology give examples of marketplaces where trust is not a given (Dubuisson-Quellier \& Neuville 2003: 17) and where participants "keep their distance" (Chantelat 2002: 532). For instance, the observation of marketplaces in Kabylie led Bourdieu to state that "relations reduced to a purely 'economic' dimension are conceived as warlike relations, which can only happen between foreigners, and the prime space for economic warfare is the marketplace." He notes how everything is then done to "substitute a personal relationship with an impersonal and anonymous one" (Bourdieu 2003: 80). Many researchers rely on observing commercial interactions to demonstrate how trust is gained face to face, "on the razor's edge" (Chantelat \& Vignal 2002), thanks to "professionals in symbolic interaction" (Le Velly 2007), or how trust implies a "re-coding of interactions" to "flirt [...] with the tone of personal relationships" (Weber 2000: 106-107), and necessitates the use of specific trust-inducing mediums (Trompette 2009).

This type of approach shows that participants in trade shows, fairs, and international marketplaces, more than seeking to carry out transactions or collect economic data, rather attempt to integrate a professional community, assimilate its norms, and in fine, wish to "personalize" their exchanges. This observation was confirmed by the fieldwork that I conducted in 2010 on two main international media events, both in Cannes ${ }^{4}$. The global export of media goods and services represented 40 billion euros back then-around 20

4. It is interesting to notice that the studies produced on the sociology of the Cannes Film Festival (Alexandre 2015, Esquerre 2012, Ethis 2001, GimelloMesplomb \& Latil 2003, Valck 2007) rarely focus on its marketplace, and even less on the television fairs where many films are traded (Lecler 2015b, 2017a, 2017b) 
quarante milliards d'euros - environ vingt milliards pour I'Union européenne ${ }^{5}$ (Organisation mondiale du commerce 2015) et quinze milliards pour les États-Unis (Bureau of Economic Analysis 2013 : 50-51). Le marché international de l'audiovisuel est donc énorme. En revanche, les " marchés audiovisuels internationaux " sont très peu marchands : ce sont d'abord des lieux de socialisation d'une même " communauté transnationale » des professionnel.e.s de l'audiovisuel international (Carroll \& Fennema 2002 ; Djelic \& Quack 2010 ; Morgan 2001). Cela les rapproche des congrès internationaux pour le monde scientifique, à ceci près que les enjeux commerciaux, même minimisés et euphémisés, demeurent leur raison d'être : il s'agit toujours fondamentalement d'y vendre des films et des programmes de télévision, mais pas forcément sur place. Ce qui prime, c'est la réussite des interactions entre participant.e.s, et donc la bonne intégration à un milieu professionnel, condition d'une participation durable au commerce international des biens audiovisuels. Ces marchés ressemblent donc très peu à ceux de la théorie économique néoclassique. La "civilité marchande ", qui est « un instrument symbolique essentiel d'intégration et de présentation de soi du groupe professionnel des vendeurs » (Pinto 2017), y prédomine. On montrera d'abord comment les marchés audiovisuels internationaux favorisent la création d'un entre-soi professionnel, puis comment la personnalisation des relations entre participant $\cdot$ e.s prime, au fond, sur la dimension marchande.

Méthodologie de l'enquête
L'analyse porte sur le Marché international des programmes
de télévision (MIPTV), lancé au début des années 1960, et
sur le Marché international du film (MIF), institutionnalisé
après-guerre en marge du festival de Cannes. Tous
deux ont lieu une fois par an au printemps, au palais des

5. Ces exportations sont très largement intra-européennes. billion for the European Union (World Trade Organization 2015) and 15 billion for the United States (Bureau of Economic Analysis 2013: 50-51). The international market of film and TV is thus enormous. However, the corresponding marketplaces are not very commercial, but instead are spaces for socialization within a single "transnational community" of international media professionals (Carroll \& Fennema 2002; Djelic \& Quack 2010; Morgan 2001). For this reason, they could be compared to the international conferences in the scientific world, except that commercial stakes, although minimized and euphemized, remain their raison d'être. It is always ultimately about selling films and television shows, but not necessarily in situ. The success of interactions between participants, significant for an adequate integration into the professional milieu, is the most important aspect, and the condition for lasting participation in the international trade of media goods. These marketplaces thus scarcely resemble the ones studied by neoclassical economic theory. "Commercial civility" predominates, as a symbolic instrument of integration and self-presentation, essential for trade professionals (Pinto 2017). We shall first demonstrate how international film and TV marketplaces facilitate social grouping of this professional community, before moving on to how the personalization of relations between participants takes precedence over the commercial dimension.

\section{Research Methodology}

The analysis concerns the International Market for Content Development and Distribution (MIPTV), launched in the early 1960s, and the International Film Market (MIF) which was institutionalized as an outcome of the post-war Cannes Film Festival. Both take place over a period of several days once a year, in Spring, and are held at the Cannes Palais des Festivals. Each event gathers around ten thousand participants 
festivals de Cannes, pendant quelques jours (fig. 1, fig. 2). Ils réunissent chacun une dizaine de milliers de participant·e·s du monde entier, les distributeurs internationaux, qui incluent à la fois les exportateurs, les importateurs et les coproducteurs internationaux de films et de programmes audiovisuels. Tou·te.s représentent un territoire pour lequel ils et elles achètent ou vendent des droits de diffusion détenus par des producteurs. Ils et elles sont ainsi les « interprètes » des goûts des publics de leurs territoires respectifs (Bielby 2011 : $530)$, ce qui les rend d'ailleurs particulièrement susceptibles d'être mobilisé·e·s par les organismes de soutien aux exportations qui subventionnent des stands nationaux sur les marchés audiovisuels internationaux (fig. 3, fig. 4). On associe cinéma et télévision parce que les films sont aussi vendus en tant que programmes de télévision et que les mêmes participant·e·s fréquentent souvent à la fois le MIF et le MIPTV. On a observé les rendez-vous commerciaux de plus d'une dizaine d'exportateurs français avec leurs acheteurs étrangers au MIPTV et au MIF. On a complété ces observationspardesentretiens avecdesexportateursfrançais de cinéma $(n=29)$ et de télévision $(n=22)$ et les organisateurs du MIF et du MIPTV $(n=4)$. Se limiter à des enquêté.e.s français.es permettait d'éviter un survol des différences entre des contextes nationaux, alors qu'ils sont essentiels pour comprendre la production, l'exportation (Steemers 2008) et l'importation (Kuipers 2015) des biens audiovisuels. D'autres chercheurs et chercheuses ont fait ce même choix en appréhendant le MIPTV à travers les professionnel·le·s des États-Unis (Bielby \& Harrington 2008) ou d'Europe de I'Est (Havens 2006). Alors que les films échangés au MIF vont du blockbuster (Miller 2001) au film d'auteur expérimental et, au MIPTV, des séries à gros budget (Hoskins \& Mirus, 1988) aux magazines d'art de vivre, les films vendus par from around the world: international distributors, including exporters, importers and international film and TV show coproducers. They each represent a geographical region for which they buy and sell distribution rights from producers. They are thus the "knowledgeable interpreters" of the varied tastes of different audiences and regions (Bielby 2011: 530); they are thus particularly likely to be mobilized by organizations that support exports and subsidize national booths in international film and TV marketplaces. For this research, I combined cinema and television because films are also sold as television shows and the same participants often attend both the MIF and MIPTV. I observed commercial meetings between more than a dozen French exporters and their foreign buyers at MIPTV and the MIF. I completed these observations with interviews with French cinema $(n=29)$ and television $(n=22)$ exporters. Limiting myself to French exporters enabled me to avoid anecessarily superficial-glimpse of the differences between national contexts, which are essential in order to understand the production, export (Steemers 2008), and import (Kuipers 2015) of media goods. Other researchers have made the same choice apprehending MIPTV through professionals from the United States (Bielby \& Harrington 2008) or Eastern Europe (Havens 2006). Although the films exchanged at the MIF range from blockbusters (Miller 2001) to experimental cinema, and at MIPTV from big budget series (Hoskins \& Mirus, 1988) to lifestyle magazines, French films sold are more likely to be festival films and French shows are destined to fill international daytime ${ }^{5}$ television schedules (Lecler 2017b). Furthermore, because I was on the exporters' side during the three days of MIPTV and the ten days of the MIF, I have

5. As opposed to "prime time," the most valued peak-time television scheduling. 
les Français·es sont davantage des films de festival et leurs programmes sont destinés à remplir le daytime ${ }^{6}$ des grilles de télévision du monde entier (Lecler 2017b) (fig. 5, fig. 6). En outre, se placer du côté des exportateurs pendant les trois jours du MIPTV et les dix jours du MIF permettait d'observer en continu un maximum d'interactions : ce sont en effet les vendeurs qui restent sur place et les acheteurs qui se déplacent d'un stand à un autre. On pouvait aussi analyser les variations du discours et des dispositifs utilisés pour la présentation d'un même bien audiovisuel à des acheteurs différents. Cette méthode est originale par rapport aux travaux sur les marchés de télévision (Bielby \& Harrington 2008 ; Favre \& Brailly 2015 ; Havens 2006 ; Moran 2009). Elle a été difficile à mettre en œuvre car les refus d'assister aux rendez-vous (qui se déroulent en face à face) ont été nombreux. Les autorisations obtenues préalablement lors des entretiens ont parfois été annulées sur place. Une dizaine d'enquêté·e·s se sont cependant prêté·e·s au jeu. Les deux accréditations indispensables pour pénétrer les places de marché ont été quant à elles obtenues gratuitement, à titre de chercheur, lors des entretiens avec les organisateurs du MIF et du MIPTV. been able to continuously observe as many interactions as possible, since, while sellers stay on site, the buyers move from one booth to the next. I was also able to analyse the variations in discourse and strategies used for the presentation of a particular media good to different buyers. This method is innovative compared with studies on television markets (Bielby \& Harrington 2008; Favre \& Brailly 2015; Havens 2006; Moran 2009). It was difficult to put into place because I was refused entry to numerous face-to-face meetings. Authorizations previously obtained during interviews were sometimes cancelled on the spot. Nonetheless, a dozen individuals agreed to take part. The two indispensable badges to gain access to the market spaces were obtained for free, for research purposes, during interviews with the MIF and MIPTV organizers.

6. Par opposition au prime time, le créneau de diffusion le plus valorisé 


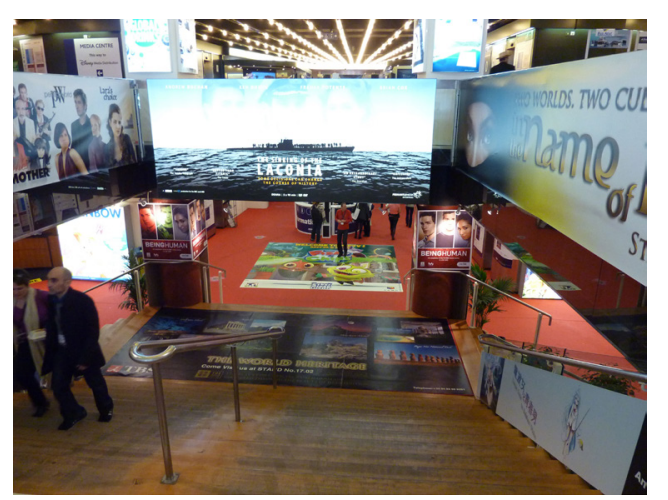

Fig. 1. Entrée du Palais des festivals au MIPTV en 2011 / Entrance to the Palais des festivals for MIPTV in 2011 (c) Romain Lecler

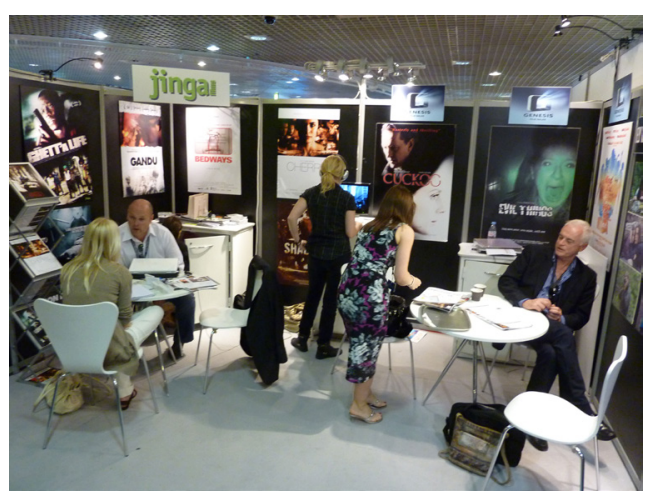

Fig. 2. Appartements loués par les exportateurs de cinéma aux abords du Palais des festivals au MIF en 2011 / Apartments rented by cinema exporters close to the Palais de festivals at the MIF in 2011 (c) Romain Lecler

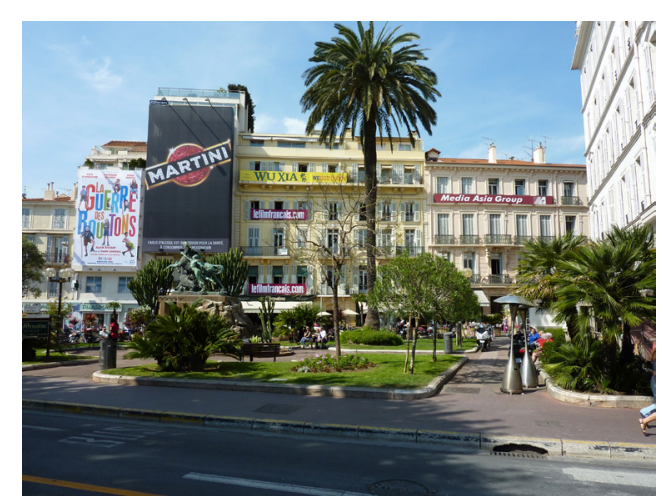

Fig. 3. Stand de promotion des programmes de télévision canadiens au MIPTV en 2011 / Promotion booth for Canadian television shows at MIPTV in 2011 @ Romain Lecler

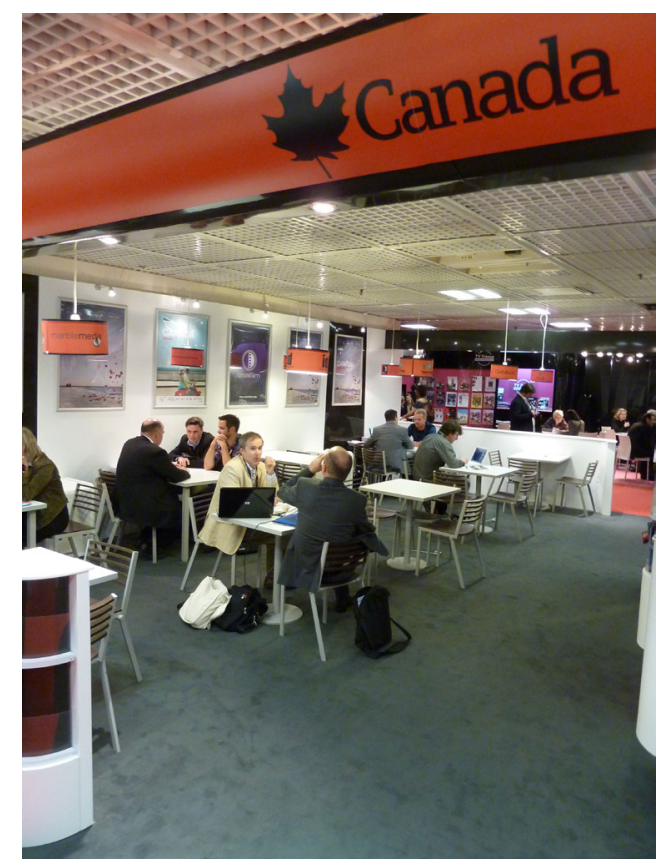

Fig. 4. Stand de promotion des films israéliens au MIF en 2011/ Promotion booth for Israeli films at the MIF in 2011 @ Romain Lecler 


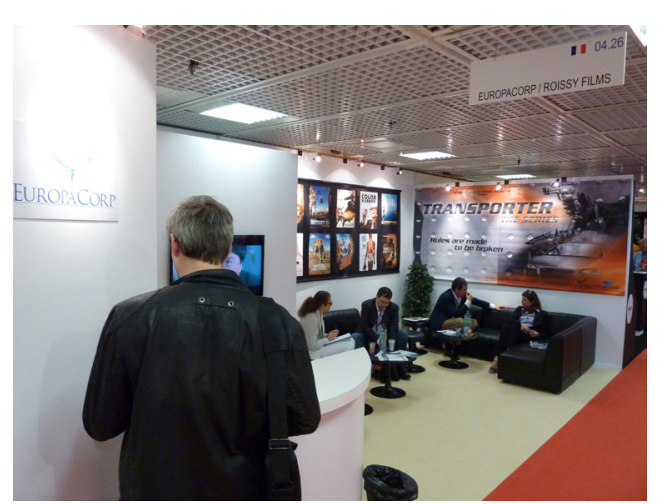

Fig. 5. Stand de la société d'exportation de cinéma Europacorp/Roissy Films au MIPTV 2011 / Europacorp/Roissy Films (cinema export company) booth at MIPTV in 2011 ๔ Romain Lecler

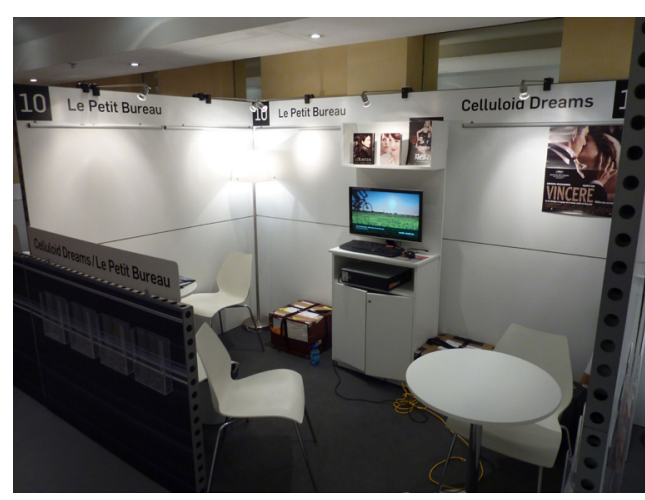

Fig. 6. Stand de la société d'exportation de cinéma Celluloid Dreams au MIPTV 2011 / Celluloid Dreams (cinema export company) booth at MIPTV in 2011 (c) Romain Lecler

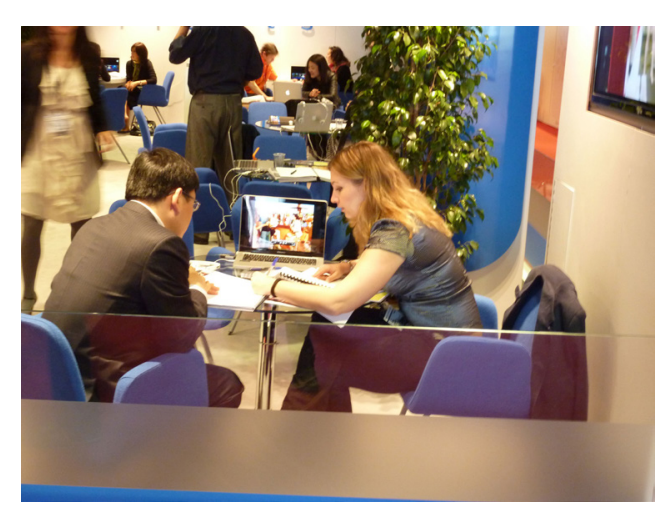

Fig. 7. Rendez-vous commercial au MIPTV en 2011 / Business meetings at MIPTV in 2011 (c) Romain Lecler

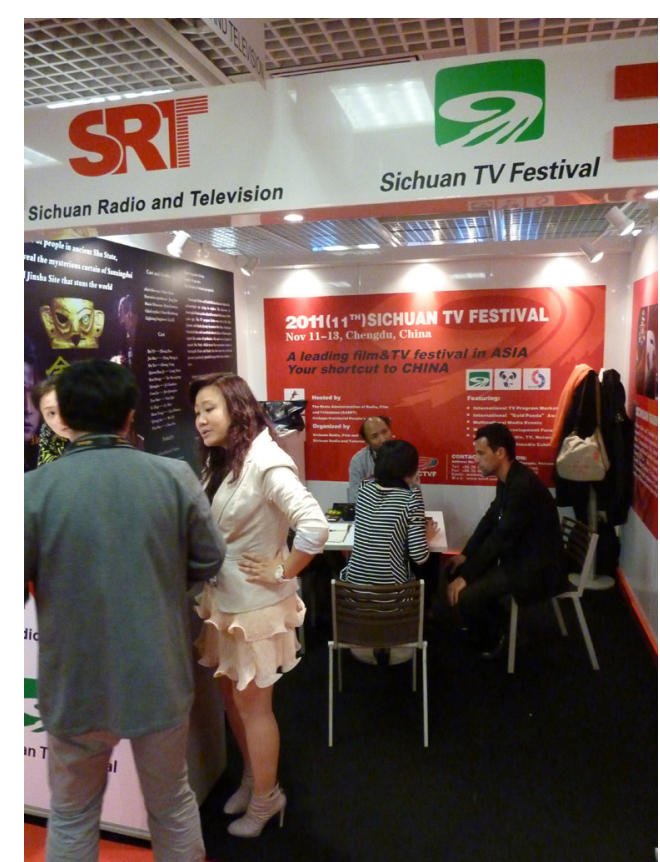

Fig. 8. Rendez-vous commercial au MIPTV en 2011 / Business meetings at MIPTV in 2011 @ Romain Lecler 


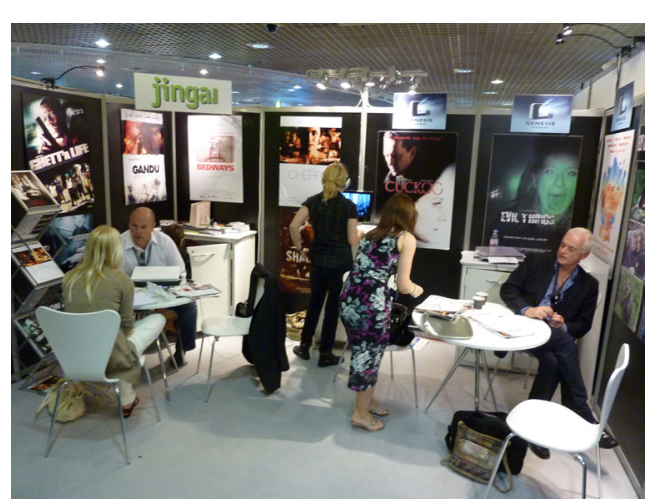

Fig. 9. Rendez-vous commercial au MIPTV en 2011 / Business meetings at MIPTV in 2011 @ Romain Lecler

\section{Un «travail émotionnel»}

Pour les enquêtée.es, le MIF et le MIPTV sont avant tout des lieux d'intégration au milieu des distributeurs internationaux. Albert Moran et Timothy Havens parlent d'ailleurs du MIPTV comme d'un " club de la télévision mondiale " (Moran 2009) et d'un événement qui " donne aux acheteurs et aux vendeurs le sentiment crucial d'appartenir à une communauté ", à une " jetset internationale » (Havens 2006 : 6-9). Le MIPTV et le MIF sont dédiés aux professionnel/le.s. Ils requièrent des badges d'accréditation que nombre d'enquêté.e.s collectionnent sur leurs bureaux, témoignant de leur ancienneté dans le milieu. Cette exclusivité favorise un entre-soi temporaire des marchés. Baptiste, trentenaire, diplômé d'une école de commerce marseillaise, vendeur de films chez Vignemale, une société moyenne, dit "retrouver les mêmes personnes dans le monde entier, c'est un peu la colo". Jérôme, quadragénaire, diplômé de littérature, russophone, ancien correspondant du journal Le Monde à Moscou, vendeur de films chez Aigoual, une société moyenne, constate : «Même ceux avec

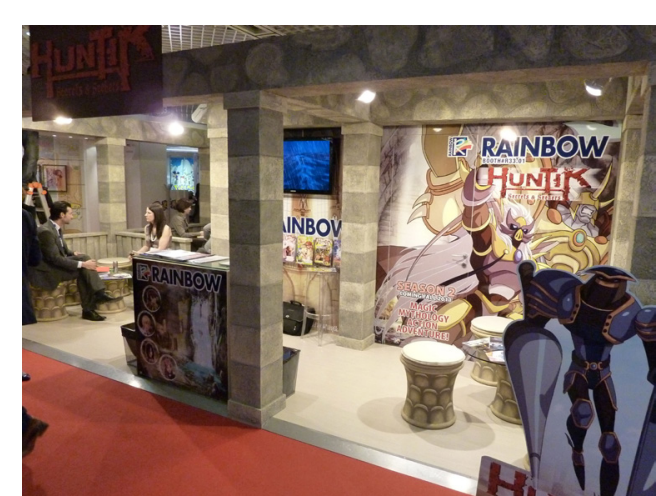

Fig. 10. Rendez-vous commercial au MIF en 2011 / Business meetings at MIPTV in 2011 ๑ Romain Lecler

\section{1. "Emotional Work"}

For the respondents of the research, the MIF and MIPTV are above all spaces for integration amongst international distributors. Albert Moran in fact speaks of MIPTV as a "kind of club that is the worldwide television industry" (Moran 2009: 21) and Timothy Havens describes it as an event that gives buyers and sellers the crucial feeling of belonging to a close-knit business "community," to an "international jet-set" (Havens 2006: 5-9). MIPTV and the MIF are for professionals. They require entry badges that many of our respondents collect on their desks as a testimony to their status in the scene. This exclusivity favours a temporary social grouping in marketplaces. Baptiste, in his thirties, a graduate from a Marseille business school, who sells films at the medium-sized company Vignemale, says that he "meets the same people all over the world; it's kind of like a summer camp." Jerome, a literature graduate in his forties, a Russian speaker and former Moscow correspondent for the French newspaper Le Monde, now selling films for Aigoual, another medium-sized company, states: "Even those with whom 
qui on a des rapports uniquement professionnels, on les voit cinq, six fois par an. On est dans un milieu où on est tous "expat", en quelque sorte ».

Sur place, l'élaboration de cet entre-soi professionnel fait l'objet d'un véritable travail sur les émotions (Hochschild 1975). Lors des rendez-vous commerciaux, ces professionnel-le's surjouent le plaisir des retrouvailles, plaisantent et badinent. Par exemple, lors d'un rendez-vous au MIPTV, trois vendeuses de Denali (une des grandes sociétés européennes d'exportation de télévision) multiplient les digressions et plaisanteries avec une acheteuse canadienne. L'une s'exclame, de façon volontairement exagérée, à propos d'une série documentaire sur les marins : "C'est magnifique, magnifique, achète ! »Elle se félicite tout haut d'échapper au quotidien des logiciels, des comptables et des financiers qui lui pèse au bureau : ici, au moins, « on travaille et on rigole ».

En dehors des rendez-vous, chacun'e s'habitue à « provoquer le hasard " en s'exposant habilement « à la contingence des événements, des rencontres ", à l'instar de ce qui a été observé pour les commissaires d'exposition sur le marché de l'art contemporain (Jouvenet 2001). Au MIPTV ou au MIF, on se rencontre aussi bien sur un stand que dans un hall, un café ou le lobby d'un hôtel. Pour se reconnaître entre eux·elles, les participant·e.s peuvent s'aider d'un annuaire qui recense toutes les personnes présentes sur place, avec leur position dans leur société et leur photo ${ }^{7}$. Ainsi, quand elle arpente le MIF, Fabiola - une quadragénaire d'origine allemande, diplômée de lettres à l'université Paris 7 , dirigeante fondatrice d'Avaloirs, une petite société d'exportation - ne cesse de saluer ses pairs en allemand, en anglais, en français et en mandarin.

7. Lors des premiers MIPTV, dans les années 1960, il existait un mur de photographies des participant.e.s. Ces annuaires sont de plus en plus souvent consultables en ligne (par les professionnel-le.s uniquement). we have a merely professional relationship, we get to see them five to six times per year. We are in a world in which everyone is somehow an expat."

On site, the creation of this professional social grouping involves serious emotional work (Hochschild 1975). During business meetings, these professionals overplay the joy of seeing each other again, and joke around and banter. For instance, during a meeting at MIPTV, three Denali saleswomen (one of the large-scale European TV export companies) digressed and joked around with a Canadian buyer at length. One of them exclaimed, in a voluntarily exaggerated way, about a documentary series on sailors: "It's beautiful, just beautiful, buy it!". She congratulates herself out loud on escaping the daily grind of softwares, accountants, and finance directors which weigh her down at the office: here, at least, "we work and have fun."

Aside from the meetings, everyone is accustomed to 'making luck happen' by skilfully exposing themselves 'to the contingency of events and meetings' (Jouvenet 2001) whether in a hallway, a café, or a hotel lobby. In order to recognize each other, some participants use a directory which identifies all of the attendees, along with their position in their respective companies and their photograph ${ }^{6}$. As she is pacing the corridors of the MIF, Fabiola, a German literature graduate of Paris Diderot University, in her forties, and the founding director of the small export company Avaloirs, constantly greets her peers in German, English, French, and Mandarin. In fact, in the marketplace, our respondents are constantly on the lookout, as demonstrated by Cyril, a DESS [the French former equivalent of a Master of Business Administration] graduate from Université

6. There was a wall of photographs of the participants who attended the first seasons of MIPTV in the 1960s. These directories are becoming more and more available to be consulted online (by professionals only) 
De fait, lors d'un marché, les enquêté·e·s sont constamment aux aguets, comme le montre le cas de Cyril, quadragénaire, titulaire d'un Diplôme d'études supérieures spécialisées (DESS, ancien diplôme professionnel de niveau master) de l'université Paris Dauphine, vendeur chez Maroon, une société moyenne spécialisée dans les dessins animés. Alors que nous sommes en entretien au bar du Hilton à Manhattan, où se termine le Kid Screen, un marché international majeur du dessin animé, Cyril repère de loin une acheteuse qui traverse le lobby. II se précipite vers elle pour lui glisser quelques mots en anglais :

« Jessica ! Salut ! Désolé, je voulais juste dire salut ! Je t’ai aperçue une ou deux fois mais je n'ai pas eu le temps de te dire salut ! Comment vas-tu ? Tu es fatiguée ? Pour l'instant tu restes sur les programmes jeunesse "preschool" ? Est-ce que tu prévois de passer à autre chose ? Ok, super ! Content de t'avoir vue!»

L'entre-soi se joue dans les nombreuses rencontres « hors marché »: soirées d'ouverture et de clôture, cocktails et verres en terrasse, repas et soirées privées. Elles exigent des participant·e·s une disponibilité constante dont Baptiste avoue qu'elle est

épuisante :

«Moi, physiquement, je mets au moins quinze jours à m'en remettre, et au moins un mois à m'en remettre mentalement parlant. Vraiment. Pendant quinze jours, tu es en sursociabilisation et en sursollicitation physique. À partir du moment où tu es là-bas, tu es un objet social. $24 \mathrm{~h} / 24 \mathrm{~h}$. Limite quand tu dors. Et il faut être aussi clair à neuf heures du matin, quand il y a ton premier Japonais qui débarque qu'à quatre heures ou cinq heures du matin, quand tu es encore ivre mort avec ton Serbe. C'est comme ça pendant quinze jours. [...] Mais seulement, à quatre heures du matin avec ton Serbe, tu es encore en train de bosser. »
Paris Dauphine, and a salesperson for Maroon in his forties, a medium-sized company that specializes in cartoon. While I was interviewing him at the Manhattan Hilton bar, where Kid Screen, a major international animation picture marketplace, was coming to an end, Cyril saw a buyer cross the lobby from afar. He rushed to say a few words to her in English:

"Jessica! Hi! Sorry, I just wanted to say hi! I glimpsed you once or twice, but I didn't get the chance to say hi! How are you? Tired? Are you still on the preschool shows? Are you planning to move onto something else? Ok, great! Great to see you!"

The social grouping plays out in numerous encounters 'outside the market': opening and closing drinks, cocktails and drinks on the terrace, meals, and private parties. They require participants to constantly be available, something that Baptiste admits can be exhausting:

"Personally, it takes me at least two weeks to recover physically, and at least a month to recover mentally. Really. For fifteen days you are physically over-sociable and oversolicited. From the moment you arrive, you become a social object. 24/7. Even when you're asleep! And you have to be as clear-headed at 9am when your first Japanese guy comes up to you, as at 4 or $5 \mathrm{am}$, when you're dead drunk with the Serbian guy. It's like that for fifteen days. [...] Except that at 4am with the Serb, you are still working." 
Cette exigence de disponibilité explique la jeunesse d'une majorité de ceux et celles qui participent à ces événements. L'immense majorité des vendeur.se's sont vingtenaires et trentenaires. Les acheteur.se·s, également jeunes dans leur majorité, sont souvent d'ancien.ne's vendeur.se's. Les participant.e.s qui ont plus de quarante ans sont généralement directeurs ou directrices des ventes, combinent les ventes à la coproduction internationale ou bien dirigent leur propre société d'exportation.

Certain.e.s comparent même cette disponibilité à celle du « tapin », pour articuler échanges marchands et intimes (Zelizer 2007). Flora, trentenaire, diplômée de Sciences-Po et de la filière distribution de la FEMIS [l'école de cinéma la plus sélective en France], vendeuse de films chez Écrins, une société moyenne, remarque ainsi, à propos du marché des films de Toronto, situé dans un grand hôtel, qu'« il y a pas mal de points communs entre les différents métiers de l'hôtel, entre les exportateurs et les prostituées " :

«Si vous n'avez pas suffisamment de monde dans votre suite parce qu'il n'y a pas assez de passage, et que vous n'avez pas assez de rendez-vous, vous allez dans le lobby, et vous attrapez les gens. C'est vraiment ça. Ça s'appelle "tapiner", d'ailleurs. C'est un mot qui est monnaie courante dans la profession. »

Dans un registre proche, Guy, qui organise des salons de programmes audiovisuels dans des pays émergents, en Europe de I'Est, au Proche-Orient et en Afrique, se compare à un entremetteur :

«Moi, je fais concierge. C'est comme si vous étiez dans un hôtel : "je voudrais rencontrer huit gonzesses"... Mon rôle, c'est de faire en sorte qu'ils se rencontrent. Point barre. Votre rôle, c'est de dire si vous voulez une blonde, grande ou pas, ou si, au contraire... c'est tout ».
This requirement of constant availability explains the young age of most participants. The great majority of salespeople are in their twenties and thirties. Buyers, also mostly young, are often former salespeople. Participants over forty are usually sales directors who combine sales with international coproductions or direct their own export companies.

Some even compare this availability to that of a "streetwalker," to articulate the relation between intimate and business exchanges (Zelizer 2007). Flora, a graduate from both Sciences-Po and FEMIS [the most selective cinema school in France], in her thirties, saleswoman for the medium-sized company Ecrins, thus says of the Toronto film marketplace, located in a grand hotel, that "there are quite a few similarities between the different jobs at the hotel, between exporters and prostitutes":

"If you don't have enough people in your suite because there isn't enough foot traffic, and you don't have enough meetings scheduled, you can go to the lobby and catch people there. That's exactly how it works. It's actually called tapiner [French slang for being a prostitute]. It's a common expression in this line of work."

Similarly, Guy, who organizes media show trade shows in emerging economies in Eastern Europe, the Middle East, and Africa, compares himself to a matchmaker:

"I play the role of the concierge. It's as if you were in a hotel: 'I would like to meet eight girls'... my role is to make sure they get together. Full stop. Your role is to say whether you want a blonde, whether you want her to be tall or not, or otherwise ... That's it." 


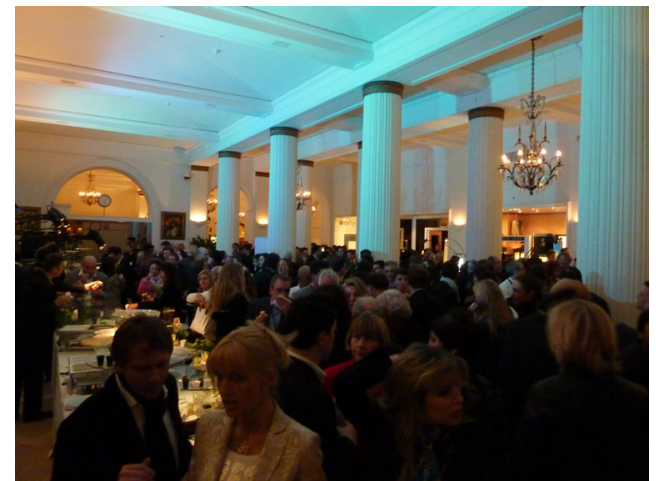

Fig. 11. Cocktail d'ouverture au MIPTV en 2011 / Opening cocktail at MIPTV in 2011 @ Romain Lecler

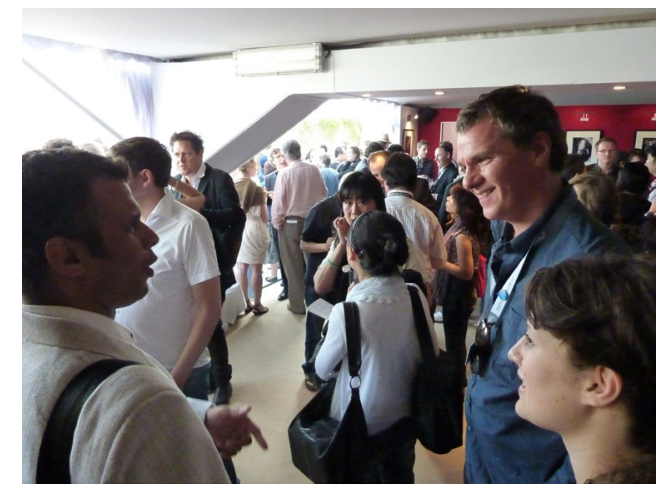

Fig. 12. Cocktail au MIF en 2011 / Cocktail at the MIF in 2011 (c) Romain Lecler

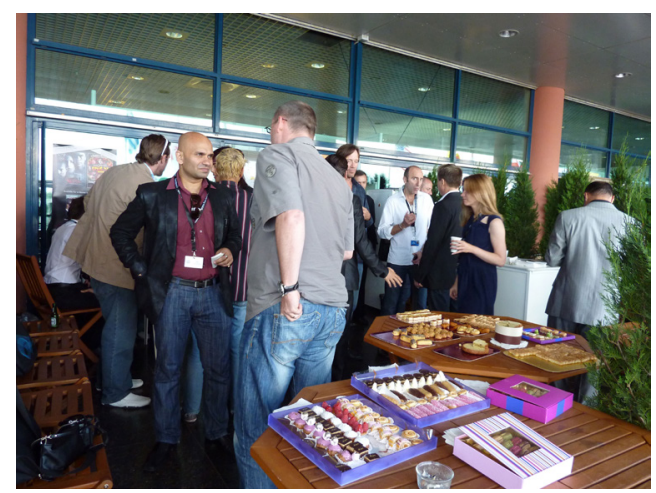

Fig. 13. Cocktail au MIF en 2011 / Cocktail at the MIF in 2011 @ Romain Lecler

\section{Rituels initiatiques}

De cette élaboration d'un entre-soi témoignent les récits de " débuts maladroits » sur les marchés (Garcia-Parpet 2005), et de rituels d'initiation. Ils incarnent, dans le jeu même des interactions sur les marchés, les tâtonnements propres à l'apprentissage du commerce international (Surubaru 2013). Ce n'est ainsi qu'après

\section{Initiation Rituals}

Stories of "awkward debuts" in the marketplace (Garcia-Parpet 2005) and initiation rituals are testament to this social grouping creation. In the game of marketplace interactions, they embody the "trial and error" characteristic of the learning process of international business (Surubaru 2013). It was only after many MIPTV events 
plusieurs MIPTV que Timothée - quarantenaire, diplômé d'études commerciales à Nice, vendeur de reportages chez Brasstown Bald depuis vingt ans - a été repéré par les acheteurs étrangers, grâce à un « coup de bol énorme » : il avait, juste avant les attentats du 11-Septembre, un reportage inédit à vendre sur l'Afghanistan des talibans. Depuis, il a enfin le sentiment d'avoir intégré le milieu :

"C'est très long d'avoir accès aux bons acheteurs-clés, tous les gens des chaînes, que ce soit les Scandinaves, les Allemands, les Autrichiens, les Espagnols. Ils étaient sympas avec moi mais sans plus : je n'étais pas l'interlocuteur indispensable [...]. Le regard qu'ils avaient sur moi a complètement changé. »

Victoria, vingtenaire d'origine bretonne, issue d'un milieu populaire (mère coiffeuse, père militaire), diplômée de langues et d'une école d'attachée de presse, sinophone, vendeuse de magazine d'art de vivre chez Sunflower, une petite société récente, n'avait pas d'accréditation quand elle s'est rendue à son premier MIPTV :

"Mon boss m'a dit : "c'est trop con que tu sois là, que tu ne puisses pas voir, c'est quand même LE marché". Pour moi, on n'avait pas pris d'accréditation, ça coûtait trop cher. C'était vraiment roots ! II m'a dit : "À 13 heures les gardiens doivent être en pause déjeuner", et on a réussi à rentrer dans le palais sans badge. Aujourd'hui ce serait impossible. Je me suis dit : "Je n'en reviens pas !" Je me suis retrouvée là sans devoir être là normalement, du coup je suis restée toute la journée, j'ai arpenté les allées : c'était vraiment le cœur de mon futur métier. »

Damien, quinquagénaire, diplômé de droit, dirigeant fondateur de Maroon, une société spécialisée dans les dessins animés, explique qu'à ses débuts, il a « mis deux MIP pour comprendre » that Timothée-a Nice business school graduate, in his forties, who has been selling documentary films for Brasstown Bald for twenty years - was spotted by foreign buyers, thanks to a "huge stroke of luck": just before the 9/11 attacks he had an unpublished documentary to sell about Taliban Afghanistan. From then on, he finally felt he had integrated into the scene:

"It takes a long time to gain access to key buyers, everyone from the channels, whether it's the Scandinavians, the Germans, the Austrians, the Spanish. They were nice to me but nothing more, I wasn't an indispensable contact [...]. The way they saw me completely changed."

Victoria is a foreign language graduate in her twenties and went to a press agent school. She speaks Chinese and sells lifestyle magazines for Sunflower, a small, new company, and did not have an entry badge when she went to her first MIPTV:

"My boss said: 'It's so dumb that you're here, and that you can't see anything; this is the marketplace.' We didn't have a badge for me, it was too expensive. It was really basic! $\mathrm{He}$ said to me: 'At $1 \mathrm{pm}$ the guards will be on their lunch break.' And we managed to sneak into the Palais without a badge. Nowadays that would be impossible. I couldn't believe it! I ended up there although I wasn't supposed to, so I stayed the whole day, pacing the alleyways: this was the very heart of my future career."

Damien, in his fifties, a law graduate and founding director of Maroon, a company specializing in cartoons, explained that when he first started out, it took him "two MIPs to understand" that it 
que c'étaient les vendeurs et non les acheteurs qui avaient des stands (« je tournais à l'envers »). Lors de ses premiers MIPTV, Timothée a également " eu une année et demie comme ça, bricolée ", en observant comme un « idiot de base » les rendezvous commerciaux de ses concurrents français.

Au MIPTV, l'observation des rendez-vous d'Anissa, trentenaire, récemment embauchée à Denali pour remplacer Catherine, partie en congé maternité, montre comment les participant·e.s néophytes sont intégré.e.s au milieu professionnel de la distribution internationale. Pendant un rendez-vous avec une acheteuse (bilingue français-anglais) représentant la principale chaîne de télévision publique finlandaise, elle multiplie en effet les «faux pas » et se voit poliment rappelée à l'ordre. Dès le début, l'acheteuse scandinave lui reproche d'avoir oublié, la veille, d'accueillir son patron, le directeur des achats de sa chaîne, sur le yacht que Denali loue pour sa clientèle en soirée. Anissa, confuse, avoue qu'elle avait oublié son téléphone à l'hôtel. Puis l'acheteuse constate qu'Anissa ne connaît pas les nouvelles orientations de programmation de sa chaîne : elle prend le temps de les lui expliquer. Anissa présente ensuite quelques-uns des programmes vendus par Denali, mais perd du temps car l'acheteuse en connaît déjà la plupart - voire en a déjà acheté certains. En outre, quand cette dernière s'intéresse à une série du catalogue, coproduite avec la Suède, Anissa n'est pas capable d'indiquer si Denali peut encore la vendre en Scandinavie. Pour une autre, elle ne sait pas préciser le nombre d'épisodes. Quand elle propose une série italienne, l'acheteuse refuse presque immédiatement car son public, dit-elle, est habitué aux programmes anglophones. Anissa finit par proposer des programmes plus anciens, mais l'acheteuse

la coupe brutalement : was the salespeople and not the buyers who had the booths ("I was going round backwards"). During his first meetings at MIPTV, Timothée also went through "a year and a half in a patchwork manner," observing his French competitors' meetings like an "idiot".

While observing MIPTV meetings with Anissa, a saleswoman in her thirties, who was recently hired by Denali to replace Catherine during her maternity leave, it is possible to observe how neophyte participants are integrated in the professional scene of international distribution. During a meeting with a bilingual French-English buyer who represented the main public television channel in Finland, she made a number of "false moves" and was politely called to order. From the onset, the Scandinavian buyer criticized her for having forgotten to greet her boss, the director of purchases of her channel, the day before, on the yacht that Denali rents for parties with its clients. Confused, Anissa admitted that she had left her phone behind at the hotel. Then the buyer remarked that Anissa did not know the new scheduling orientation that her channel had taken, and took her time to explain it to her. Anissa then presented some of the new shows offered for sale by Denali, but was wasting her time because the buyer already knew most of them-and had even already bought some. Furthermore, when the buyer took an interest in a series from the catalogue that was co-produced with Sweden, Anissa could not indicate whether Denali could already sell them in Scandinavia. For another show, she could not remember the number of episodes available. When she suggested an Italian series, the buyer immediately refused because her audience, she said, is used to English language shows. Anissa ended up suggesting some older shows, but the buyer interrupted her sharply: 
"Acheteuse : - Je connais les vieux programmes...

Depuis combien de temps travailles-tu en fait?

Anissa : - Pourquoi ?

Acheteuse : - Juste pour savoir...

Anissa : - J'ai commencé en juillet dernier...

Acheteuse : - Mmh... Ok..

Anissa : - Ça se voit tant que ça ? [en français]

Acheteuse : - II faut bien commencer quelque part ! »

Et l'acheteuse de conclure sur un ton mandarinal : «Ok.

Très bien. Félicitations à Catherine. »

En une petite demi-heure, elle attire ainsi l'attention d'Anissa sur la nécessité d'une bonne préparation des rendez-vous, d'un respect des engagements pris, d'une connaissance plus précise des programmes, d'un suivi plus attentif de la relation marchande. Tous ces rappels à l'ordre n'ont pourtant pas obéré le bon déroulement du rendez-vous, que l'acheteuse, en professionnelle aguerrie, a largement guidé. Le rendez-vous d'Anissa a ainsi constitué plutôt un rituel d'initiation qu'une négociation commerciale.

\section{Le sens du placement}

L'élaboration de cet entre-soi se double enfin d'une inculcation des hiérarchies qui structurent ces marchés. Le plan du MIPTV distribué aux participant.e.s oppose ainsi deux secteurs. Le premier, en rouge, au sous-sol, est dédié à toutes les petites sociétés dont les stands, exigus et très nombreux, sont disposés de part et d'autre d'un long couloir central très fréquenté. Le second, en vert, accueille les sociétés les plus importantes, aux étages supérieurs, comme BBC, Paramount ou Universal, ou bien comme Fremantle et HBO sur le parvis ou la plage. Là, les stands sont plus vastes, les espaces plus feutrés, la plupart disposent de terrasses avec vue sur la mer : ils ressemblent à ces « maisons traditionnelles » des foires viticoles, « aménagées pour que l'on ne se sente autorisé
Buyer: - I know the old shows... By the way, how long have you been doing this?

Anissa: - Why?

Buyer: - l'm just curious..

Anissa: - I started last July..

Buyer: $-\mathrm{Hmm}$... Ok ...

Anissa: - Is it that obvious? [in French]

Buyer: - Well you have to start somewhere!

And in a haughty tone, the buyer concluded: "- Ok. Very well. Congratulations to Catherine."

In less than half an hour, she brought Anissa's attention to the fact that good preparation for meetings, respecting engagements, more precise knowledge of shows, and more attentive compliance to commercial relations were necessary. All of these calls to order did not, however, impede on the smooth running of the meeting, which the buyer, as a seasoned professional, mostly guided. Anissa's meeting thus constituted more of an initiation ritual than a business negotiation.

\section{Being In The Right Place At The Right Time}

The creation of this social grouping is coupled with an instilled set of hierarchies that structure these marketplaces. The MIPTV map that is distributed to participants thus pits two sectors against one another. The first, in red, in the basement, is reserved for small companies whose numerous, cramped booths are arranged on each side of a long and busy central corridor. The second green sector hosts larger companies such as the BBC, Paramount, Universal on the upper floors, or Fremantle and $\mathrm{HBO}$ on the piazza or the beach. Here, the booths are larger and quieter; most of them have sea-view terraces: they resemble the traditional houses of wine fairs, "fitted out so that you only feel like you can enter if you already have a meeting set up, or a business card that would be 
à y pénétrer que si l'on a déjà un rendez-vous ou une carte de visite qu'un homme d'affaires puisse prendre au sérieux » (GarciaParpet 2005). Aux lisières du Palais des festivals, ces sociétés ont

" l'autorisation de s'extraire des frontières du salon " (Brailly \& Coulondre 2016 : 177-178). L'organisatrice des MIPTV explique :

« Ils sont dans toutes les grosses tentes. La plage. L'eau est là. [...] Après vous avez en haut, au troisième étage, tous les studios américains [...]. Ils veulent tellement d'espace. Et ils veulent aussi un environnement à eux. [...] Ils n'ont pas besoin d'être dans le cœur du marché. Ils ont besoin qu'on ne les fasse pas chier, qu'on leur donne leur endroit privé, et qu'on respecte le fait qu'ils veulent construire un bureau ou whatever. "

Les foires, salons et marchés internationaux constituent un " espace des positions statutaires » (Menger 2013). Plusieurs sociologues les ont donc rapprochés d'autres événements internationaux tels que les compétitions (sportives, culturelles, etc.) et les remises de prix, où les rituels et la réputation dominent (Moeran \& Strandgaard Pedersen 2011). Ils révèlent en effet des « niveaux variés de prestige » (Havens $2006: 9$ ) et « rendent [l]es positions relatives des entreprises exposantes directement visibles pour un observateur expérimenté » (Skov 2006 : 768).

Mais la répartition des stands au MIF ou au MIPTV n'a pas uniquement une dimension informative sur la distribution des positions des sociétés dans le marché. Elle a également une vertu intégrative. Elle dote en effet les participant·e.s d'un sens de l'orientation dans ce marché puisque les sociétés conservent généralement leurs stands d'une année sur l'autre. Les participant.e.s peuvent ainsi y «trouver leur place ». Au MIF, « il n'y a que les petites sociétés qui sont dans le Palais [...] et ce taken seriously" (Garcia-Parpet 2005). At the edges of the Palais des festivals, these large companies are "allowed to be out of the trade show borders" (Brailly \& Coulondre 2016: 177-178). The MIPTV organizer explains:

"They are all in big tents. On the beach, with direct access to the sea. [...] The American studios are all at the top, on the third floor, [...] They want so much space. And they want their own environment. [...] They don't need to be at the centre of the market. They don't want anyone to bother them, they want their own private space, and for us to respect the fact that they want to build an office or whatever [in English]."

The trade fairs, shows and international marketplaces constitute a "space of statutory positions" (Menger 2013). Many sociologists have thus likened them to other international events such as competitions (sports, cultural, etc) and awards, where rituals and reputation reign supreme (Moeran \& Strandgaard Pedersen 2011). They indeed reveal "various levels of prestige" (Havens 2006: 9) and "make the relative positions of exhibiting companies directly visible to the trained eye" (Skov 2006: 768).

However, the booth distribution at the MIF or MIPTV does not only inform participants about the distribution of company positions in the marketplace. It also serves an integrative purpose. It provides participants with a sense of orientation in the marketplace since companies usually keep their booths from one year to the next. The participants can thus find both their way and their place in the market. At the MIF, "Only the small companies are in the Palais [...] and that's not our spirit," for Claudia, an Italian saleswoman, foreign 
n'est pas l'esprit de la maison », explique Claudia, quarantenaire, d'origine italienne, diplômée en langues, et vendeuse chez Grand Paradis. Elle est ainsi installée avec sa société en face de l'entrée du Palais, dans un appartement avec " un coin de balcon ", tout comme les autres grandes sociétés d'exportation qui louent des appartements ou des suites d'hôtel tout au long de la Croisette. Jérémy, directeur des ventes chez Carré, une société de taille plus modeste, a de son côté décidé de retourner dans le Palais après avoir loué pendant longtemps un appartement sur la Croisette :

" On tient à maximiser nos chances de capter les acheteurs. Les appartements, c'est dangereux, si on n'est pas incontournable. [...] On n'aura pas ce qu'on appelle le "passage", les gens qui viennent là parce qu'ils ont un quart d'heure à tuer. »

Quand ces participant·e·s évoluent d'une société à une autre, ils et elles conservent ce sens de l'orientation dans le marché et savent quelle sera leur place au MIF ou au MIPTV du fait de leur nouveau poste. De nombreux espaces exclusifs (terrasses privées, cocktails, yachts et villas loués pour l'occasion), propices aux dépenses somptuaires, renforcent d'ailleurs cette expérience d'inculcation des hiérarchies et d'apprentissage du sens du placement. Denali débourse par exemple 35000 euros au MIPTV pour louer un yacht et organiser des « rendez-vous VIP » en soirée - et ce n'est « rien par rapport au stand ", confie l'une des vendeuses. Seul'e.s les client·e.s et partenaires de cette société, l'une des plus importantes en Europe, y ont accès. language graduate; in her forties, working for Grand Paradis. Her company is indeed settled in front of the entrance of the Palais, in an apartment with a "little bit of balcony," just like the other large export companies that rent apartments or hotel suites along the Croisette. Jeremy, sales director for Carré-a slightly more modest company - has, for his part, decided to go back into the Palais after having rented an apartment along the Croisette for a long time:

"We want to maximize our chances of captivating buyers' attention. Apartments are dangerous if you're not a major company. [...] You don't get much footfall, people don't come by just because they have fifteen minutes to kill."

When these participants move from one company to another, they keep this sense of orientation in the market: they know what their place at the MIF or at MIPTV will be because of their new position. Many exclusive spaces (private terraces, cocktails, yachts, and villas rented out for the occasion), prone to lavish expenses, further reinforce this experience of hierarchical inculcation and figuring out a sense of one's place. Denali, for instance, spends 35,000 euros at MIPTV on renting a yacht and organizing "VIP meetings" at parties - and that's "nothing compared with the booth," a saleswoman confesses. Only the clients and partners of this company, one of the largest in Europe, have access to its exclusive spaces. 


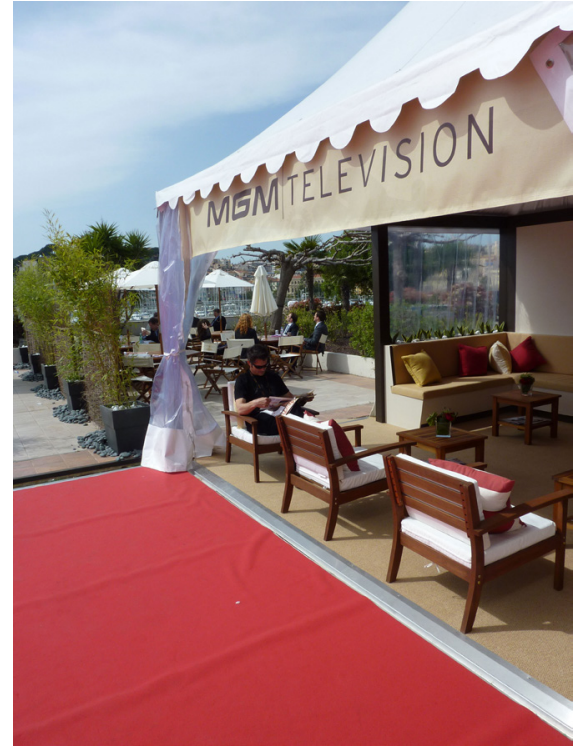

Fig. 14. Terrasse de Metro Goldwyn Mayer au MIPTV en 2011 / Metro Goldwyn Mayer terrace at MIPTV in 2011 @ Romain Lecler

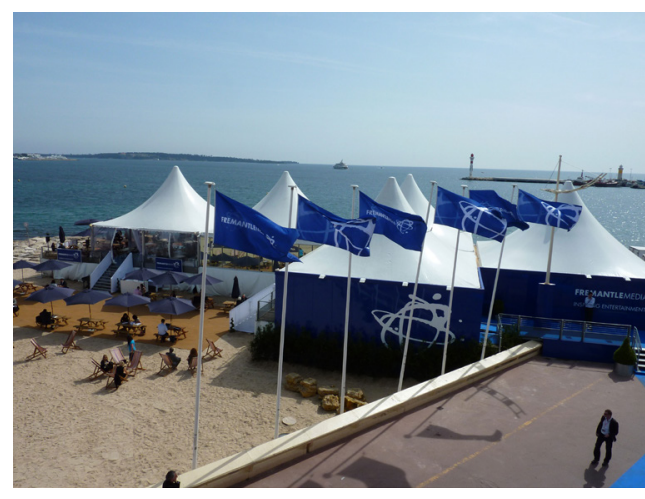

Fig. 15. Terrasse d'Endemol au MIPTV en 2011 / Endemol terrace at MIPTV in 2011 @ Romain Lecler

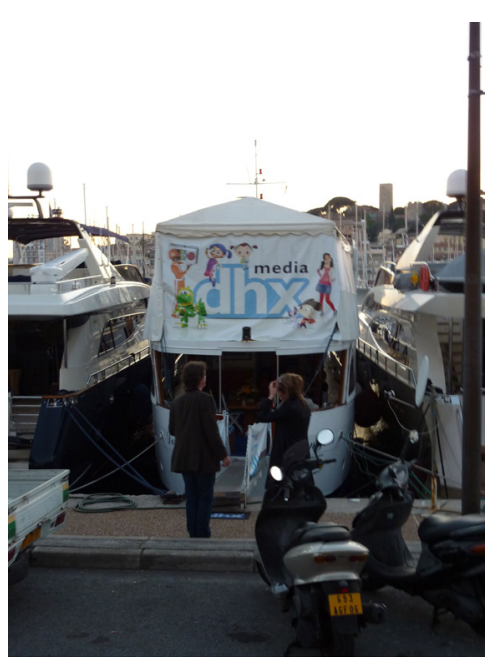

Fig. 16. Yacht d'une société d'exportation au MIPTV / Export company yacht at MIPTV (C) Romain Lecler

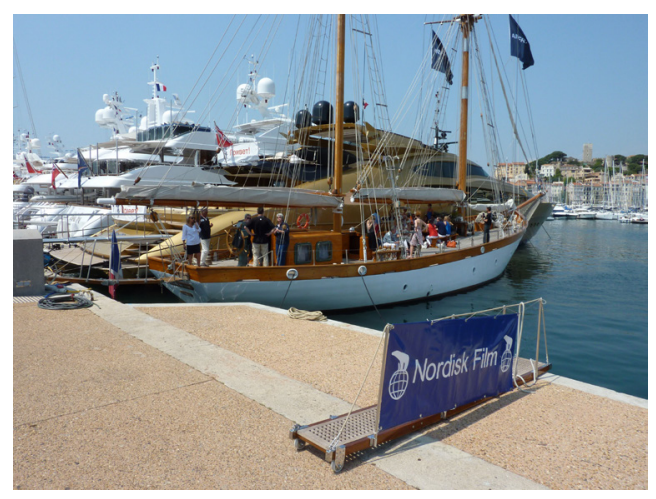

Fig. 17. Yacht d'une société d'exportation au MIF / Export company yacht at MIPTV and the MIF (c) Romain Lecler 


\section{Personnaliser des relations professionnelles : Ia minimisation du registre marchand}

Bien avant d'être des lieux de transaction ou d'information économique, le MIF et le MIPTV sont des occasions de personnaliser des relations à distance entre partenaires étrangers. De manière surprenante, les enquêté $\cdot e \cdot s$ s'efforcent en effet de minimiser ce qui devrait pourtant être au cœur des interactions : la négociation d'un prix. Ils et elles sont pourtant, à quelques exceptions près, tou.te's issu.e.s de formations commerciales. Par exemple, quand Cyril retrouve au MIPTV une acheteuse québécoise, le prix des programmes n'est jamais discuté ni même évoqué. II commence par offrir des bonbons Titeuf (un programme qu'il vend) à son acheteuse, " pour les enfants »: ce type de cadeaux, très fréquents au MIPTV, participe à la transformation de la relation qui se rapproche du registre de l'échange, tout en rappelant l'objet de la négociation commerciale (Sciardet $1996: 43)$. « Comment vontils ?... Et ta famille ?... Et toi ? » Assez rapidement, il demande à son acheteuse si Samsam, un programme qu'il lui a vendu récemment, marche bien au Canada. C'est le cas, assure-t-elle : «As-tu quelque chose de nouveau ? ». II présente un programme encore en production, Casper. II précise sa durée, le nombre d'épisodes et estime qu'il sera livré probablement entre janvier et avril 2012 ("C'est demain ! »). II lui montre un extrait sur un iPad, qui déclenche l'enthousiasme de l'acheteuse. Tous deux s'émerveillent du travail sur les expressions des personnages. Elle inscrit une étoile dans son cahier en face de Casper, puis lui demande s'il a d'autres programmes à lui proposer. II ouvre son classeur, pas très convaincu:

« Cyril : - Un truc avec des monstres à grandes dents ? " Acheteuse : - C'est une pub pour les dentistes ?"

Cyril : - Non, un truc de science-fiction. ”

\section{Personalizing Professional Relations: Minimizing Commercial Language}

Before being transactional or economic data spaces, the MIF and MIPTV constitute the means of personalising long-distance relations between foreign partners. Surprisingly, the respondents try their best to minimize what should in fact be at the heart of the interactions-negotiating a sales price-despite the fact that they are all, almost without exception, from sales backgrounds. For instance, when Cyril encounters a buyer from Quebec at MIPTV, show prices are never mentioned, not even alluded to. He begins by offering the buyer some Titeuf sweets [Titeuf is a cartoon he is selling] "for her kids": this type of gift, which is very frequent at MIPTV, contributes to the transformation of the relationship towards a logic of exchange, while reminding the buyer of the object of the commercial exchange (Sciardet 1996:43). "How're they doing?.. And your family?... How about you?" Quite rapidly, he manages to ask the buyer if Samsam, a show she recently bought from him, was doing well in Canada. "Absolutely," she answers: "Do you have anything new?" He shows her a cartoon still in production, Casper, informings her of the length and number of episodes, and that it would probably be ready between January and April 2012 ("That's tomorrow!"). He shows her an extract on an iPad which makes her enthusiastic. Both marvel at the work put into character expression. She scribbles a little star in her notebook next to Casper, before asking him if he has any other shows that he might like to show her. He opens his folder, unconvinced:

"Cyril: - Something with big-toothed monsters?

Buyer: - Is it an advert for dentists?

Cyril: - No, science-fiction." 
Tous deux se connaissent bien : le refus du programme est ainsi éludé sur le ton de la plaisanterie. Le reste du rendez-vous est consacré à évoquer Le Petit Prince, qu'elle a acheté à Cyril « contre l'avis de tous " au sein de sa propre chaîne. II lui offre pour finir un autre gadget adapté d'un dessin animé : un réveil pour enfants. Elle conclut : " J'adore ce métier ! " Comme on le constate, ni le prix ni même la décision d'acheter ne font l'objet de la discussion dans l'interaction. On décide plus tard, à distance, comme sur les marchés viticoles où on retrouve cette même " dénégation de [l'] aspect commercial » et où « on ne réalise pas les affaires tout de suite, c'est plutôt pour le contact » (Garcia-Parpet 2005). Ici, Cyril et son acheteuse mettent en fait en scène, sur le moment, le plaisir de se retrouver. Ils évoquent des éléments de la relation passée et en balisent d'autres à venir : la négociation du prix viendra plus tard, quand chacun aura regagné son bureau, à distance.

Lors de ces événements, les rendez-vous ne sont « commerciaux » que dans la mesure où ils ne permettent d'actualiser et d'entretenir une relation commerciale de long terme entre professionnel.le.s. C'est d'ailleurs « pour les relations » que Yannick se rend au MIPTV

$$
\text { où il « ne signe quasiment rien »: }
$$

« Ce qui est signé, c'est parce que c'est l'occasion de se serrer la main, de boire un coup, c'est tout, mais ça a évidemment été négocié en amont, par Skype, par téléphone, par mail, on s'est mis d'accord sur toutes les choses, on vient avec le document prêt. »

\section{Christophe abonde dans son sens :}

«On essaie d'avoir des déjeuners calés quand même avec des acheteurs, parce que c'est plus sympa même si on ne parle pas spécialement affaires. Parce que les liens se
They both know each other well: the explicit refusal of a show is avoided through banter. The rest of the meeting is dedicated to The Little Prince, which she bought from Cyril "against everyone's advice" on her own channel. Eventually, he offers her another gadget adapted from a cartoon: a children's alarm clock, and she claims "I love this job!" As shown here, neither the price nor the decision to buy are raised during the conversation. It is decided later on, at a distance, as on wine marketplaces where the same "commercial denial" is found, and where business is not done immediately, but contact is made (Garcia-Parpet, 2005). Here, Cyril and his buyer rather display, on the moment, the pleasure of meeting each other again. They bring up memories of a previous meeting and hence prepare those which are to come: price negotiation will take place later, when each of them is back at the office.

During these events, meetings are therefore less "commercial," so to speak, than a means of maintaining a long-term commercial relationship between professionals. That is precisely why Yannick goes to MIPTV in the first place, "for the encounters," since he "hardly passes any formal agreements":

"When we do sign here, it's because we have an opportunity to shake hands, have a drink, that's it, but it has all been negotiated beforehand, of course, by Skype, on the phone, via email, we come to an agreement on everything beforehand and arrive with the document ready."

\section{Christophe tends to agree:}

"We try to set up lunches with buyers, because it's nicer, even if we don't really talk about business. You start to build bonds, which is extremely important in the end. Between 
créent, et c'est hyper important finalement. Entre moi qui ai un portrait du dalaï-lama [un documentaire] et Europe Images qui a aussi un portrait du dalaï-lama, avec un producteur relativement similaire, le contact qu'on a avec l'acheteur va pouvoir faire la différence à un moment. C'est là que le lien personnel importe. »

Même au MIF, où les acheteur.se·s décident sur place d'acquérir des films, le registre commercial reste minimisé. Par exemple, lors d'un de ses rendez-vous, Fabiola propose d'entrée de jeu à un acheteur italien un prix pour un film qui a été sélectionné dans la section Un certain regard. L'acheteur demande réflexion. C'est la seule fois où un prix est formulé au cours des rendez-vous observés. Mais pendant les vingt minutes restantes, Fabiola montre à son acheteur un blog italien sur le cinéma, lui énumère tous les pays où elle a déjà vendu son film et raconte nombre d'anecdotes sur les caprices et exigences du documentariste qu'elle suit depuis des années, Frederick Wiseman. L'essentiel de l'interaction se joue ainsi finalement dans la relation marchande que l'exportatrice réussit à entretenir, une fois évacuée la question de la transaction

financière.

La fixation même des prix est cantonnée à de brefs passages sur les stands, ou même à des échanges par téléphone ou par mail. Il arrive par exemple à Fabiola de valider une offre par un simple yes par sms depuis son téléphone. Quant à l'accord, le deal memo, il se réduit à quelques points-clés « pour ne pas passer la nuit à faire un contrat », souligne Jérôme. " Ça, on le signe pendant le festival, et après, quand on rentre au bureau, les juristes envoient un contrat de quarante pages plus élaboré ", précise Melvin, trentenaire, diplômé d'une école de commerce de Reims, vendeur de films chez Cervin, une des trois plus grandes sociétés françaises du secteur. Ce sont en réalité les négociations longues qui sont l'exception, constate Flora my film about the Dalaï-Lama and Europe Images who also made a film about him with the same kind of producer, the contact made with the buyer will make a difference later on. That's where the personal connection matters."

Even at the MIF, where buyers decide whether or not to purchase films onsite, commercial language is minimized. For instance, from the outset of a meeting, Fabiola makes an offer to an Italian buyer for a film that has been nominated for the Un certain regard selection at the Cannes Festival. The buyer wants to think about it. It is the only time that a price is discussed during one of the meetings observed. However, in the following twenty minutes, Fabiola shows the buyer an Italian cinema blog, lists all the countries where she already sold the film and tells various anecdotes about the documentarymaker Frederick Wiseman's caprices and demands, whom she has been following for several years. The critical part of the interaction rested on the commercial relationship that the exporter manages to maintain, once the financial question is dealt with.

The fixing of prices is confined to brief moments on the booths, or even in telephone or email exchanges. Fabiola manages to validate an offer by texting a simple "yes" on her phone. As for the "deal memo," it was reduced to a few key points "so as not to spend the whole night drawing up a contract," as Jérôme notes. "We sign it during the festival, and afterwards when we're back at the office, the lawyers send a more elaborated forty-page contract," says Melvin, a film seller in his thirties, graduate from a business school in Reims, working for Cervin, one of the three biggest French companies in the field. In reality, long negotiations are an exception, Flora states: 
«Des distributeurs avec qui j'ai l'habitude de travailler, on fait à peu près toujours le même partage de recettes. On peut faire un deal en cinq minutes debout en train de boire une coupe de champagne : 'Bon, allez : '38' [38 000 euros], aux conditions habituelles"... Et je sais que, le lendemain, j'envoie mon contrat : c'est fait en deux minutes parce qu'on a l'habitude de travailler ensemble et on se met juste d'accord sur un prix. Pour le reste, on sait que tout roule. En revanche, il m'est arrivé de négocier des deals pendant une heure et demie à deux heures. C'est affreux, c'est horrible. C'est très, très dur. C'est avec les distributeurs en général avec lesquels je n'ai jamais travaillé, des gens très nerveux qui discutaient de tout pendant des heures, et qui après revenaient en arrière. »

\section{Incarner la relation marchande}

Les enquêté.e.s fréquentent ainsi un nombre limité de partenaires étrangers avec lesquels ils et elles entretiennent des échanges répétés. Malgré la distance géographique, ils et elles « s'approprient les clients de leur portefeuille ", exactement comme les commerciaux d'une banque qui voient leurs clients régulièrement dans leur bureau, et qu'ils et elles « "partagent" le moins possible » en installant des « connivences fortes et [...] une relation de style "privé" [...] qui comporte l'émergence d'une relation quasi amicale " (Roux 2009). Claudia raconte par exemple comment « ses" distributeurs turcs, qui « ont l'habitude » de travailler avec elle, voient d'un mauvais œil l'idée de repartir de zéro avec un autre vendeur de films chez Grand Paradis : " Je sais ce qu'ils aiment, je sais quel type de films ils font, je connais leurs habitudes, c'est logique. " C'est cette connivence qui explique comment Claudia parvient à imposer à ses acheteurs des packages de films :

« Ils savaient bien qu'ils n'allaient pas arriver, prendre les gros titres du catalogue et nous laisser les autres. C'est un peu facile. On ne leur mettait pas du tout le couteau sous la
"We always make roughly the same share of takings, with the distributors that I usually work with. We can agree on a deal in five minutes whilst drinking a glass of champagne: 'OK, how about, '38' [38,000 euros] with the same conditions as usual'... And I know that the next day l'll send my contract, and it's done and dusted in two minutes, because we're used to working together and we just need to agree on the price. For everything else, we know that it will all work out fine. But l've already negotiated deals for an hour and a half to two hours. It's just awful, horrible. Very very hard. That's usually with distributors that I've never worked with before, very nervous people who want to go through every last thing in detail, and then afterwards change their mind."

\section{Embodying the Commercial Relationship}

The respondents see a limited number of foreign partners with whom they have frequent meetings. Despite the geographical distance, they "appropriate the clients in their portfolios," just like bank sales representatives who regularly see their clients at their office; they "share them as little as possible," establishing "strong, complicit feelings and [...] a 'private' relationship style [...] which even resembles a virtually informal relationship" (Roux 2009). Claudia recalls how even "her" Turkish distributors, who "are used to" working with her, take a dim view of the idea of starting from scratch with another film seller at Grand Paradis: "I know what they like, I know what type of films they make, I know what they're used to, it just makes sense." This complicity explains how Claudia manages to impose film 'packages' on her buyers:

"They knew very well that they weren't going to be able to take big titles from the catalogue and leave us the rest. It's a little too easy. We weren't forcing them at all, but they were 
gorge mais d'eux-mêmes, ils disaient : "Je te prends ceux-là, et je te prends trois ou quatre petits" - qui les intéressaient aussi d'ailleurs. »

Sur place, au MIF ou au MIPTV, l'enjeu est alors d'arriver à incarner le plus possible la relation marchande au cours d'interactions brèves et standardisées. Un outil témoigne de ce travail : c'est le cahier posé par tous les acheteurs et les vendeurs devant eux, à chaque rendez-vous, où ils notent les DVDs à envoyer et, plus largement, tout type d'informations. Au fur et à mesure de la fréquentation des événements internationaux, ce cahier s'étoffe, permettant de retenir les goûts et dégoûts d'un acheteur, comme

l'indique Christophe :

« II faut qu'il puisse avoir confiance, qu'il puisse savoir quand on lui dit : "ça, c'est pour toi", qu'il sache qu'on n'est pas en train de lui vendre un truc sur le Talmud alors que c'est une chaîne indonésienne ultra-musulmane. ”

Pour Fanny, quadragénaire, diplômée d'un master de communication audiovisuelle à Nantes, vendeuse depuis une dizaine d'années chez Marcy, une importante société spécialisée dans les documentaires, c'est « tout un art » de savoir adapter la présentation d'un programme à son interlocuteur :

"L'acheteur qui va aller chercher de la nature, on va lui pitcher le programme angle nature, l'autre qui cherche hommes animaux, on va lui pitcher hommes animaux, celui qui cherche environnement, on va lui pitcher environnement. Ça peut évoluer. On y réfléchit beaucoup, par contre. »

C'est cette incarnation qui permet à Mathilde d'affirmer : « On n'est pas non plus dans une espèce d'industrie commerciale basique, on est beaucoup dans le contact humain, dans l'intuitu personae. " saying it themselves 'I'll take these, and three or four little ones'-which also interested them."

On site at the MIF or MIPTV, the key is to bring the commercial relation to life during brief and standardized interactions. The notebook which all buyers and sellers place in front of them before each meeting, used to note down the DVDs they need to send and all kinds of other information, is a key tool. The more international events attended, the more this notebook is filled, detailing a buyer's likes and dislikes, as Christophe states:

"They have to be able to trust us; if we say, "this is definitely for you,' they have to know that we're not just trying to sell them something on the Talmud when they're from an ultra-Muslim Indonesian channel."

Fanny, a seller in her forties, with a master's degree in media communications from Nantes, has been working for Marcy, a big company specializing in documentaries, for about ten years. For her, knowing how to "pitch" [in English] the presentation of a show to one's audience is "an art":

"For the buyer looking for nature, we'll pitch them the show's nature angle, if they're looking for animals, we'll pitch them the animals, if they're looking for the environment, we'll pitch them the environment. And it may change. We think it through a lot, though."

As a result of this portrayal, Mathilde affirms that "we are by no means in the ordinary commercial business industry, we are 
Dominique parle, de son côté, de fit entre un·e vendeur·se et son acheteur.se :

« L'acheteur vient vous voir : il connaît votre société, il sait qu'il y a sa réputation. Et puis après le désir de la relation interpersonnelle qui s'installe. II arrive toujours dix minutes en retard, et il doit toujours partir avant la fin du rendezvous : donc en gros, vous avez un quart d'heure. Les cinq premières minutes, vous les passez à lui demander comment se sont passées ses vacances, comment va son petit-fils et si son chien s'est remis de la fracture de sa patte. »

Pour Flora, c'est une véritable compétence professionnelle que de montrer de l'intérêt pour les acheteur·se·s :

« C'est très important d'avoir des relations personnelles avec les distributeurs. Faire les dîners, connaître leur vie. Concrètement ça veut dire qu'on est forcés d'avoir de bonnes relations avec les gens et de s'intéresser à eux, de connaître leur vie, de savoir le prénom de leurs enfants, de leur demander où ils vont en vacances, de retenir pour la fois d'après, d'échanger des informations sur d'autres sujets que les films. C'est ça qui marche. II n'y a que ça qui marche, mais bien sûr ! [...] C'est ça, le talent d'un vendeur : c'est de s'en souvenir, d'aimer ça, et de faire ça naturellement. Et puis, sinon, c'est chiant. Je vois bien qu'il y a des vendeurs que ça n'intéresse pas. »

Cette incarnation des relations marchandes s'exprime aussi à travers l'élaboration de «styles » professionnels, comme chez les commissaires d'exposition sur le marché de l'art contemporain (Jouvenet 2001). Flora distingue ainsi ceux « qui sont énormément sur le terrain de la séduction » d'autres « qui sont beaucoup sur le terrain de l'affectif ». À propos de ses collègues de Montcalm : «C'est zéro séduction, et de l'affectif dans des proportions très definitely involved in human relations, in the intuitu personae." Dominique talks about how to fit in with a buyer:

"The buyer comes up to you, they know your business and its reputation, and that's how an interpersonal relationship starts to emerge. They always arrive ten minutes late and they always have to leave before the end of the meeting, so, basically, you've got fifteen minutes. The first five minutes are spent asking them how their holidays went, how their grandson is doing and if their dog has gotten over a fractured paw."

For Flora, showing interest in buyers is a real professional skill:

"It's really important to maintain good interpersonal relationships with distributors. Going to dinners, knowing about their private life. Basically, it means that we're forced to be good at communicating with people and take an interest in their lives, know the names of their children, ask them where they spent their holidays, and remember all that for the next meeting-basically, you've got to be able to talk about things other than films. That's what works, in the end. In fact, that's the only thing that works, of course! [...] That's what makes or breaks a seller, if they can remember that, enjoy it, and do it with flair. Otherwise it's a real pain. And l've noticed that some sellers just aren't interested in that."

The portrayal of commercial relationships is also expressed through the development of professional "styles" as can be seen with contemporary art curators for instance (Jouvenet 2001). Flora distinguishes between those "who exchange mostly through seduction" and those "who are more emotional." With colleagues from Montcalm, "there is a zero-seduction policy and emotions are permitted in reasonable quantities." For those from Grand Paradis, 
raisonnables. " À propos de ceux de Grand Paradis : " C'est faire la fête avec les clients. " Quant au style d'Écrins (le sien) : "C'est pas de séduction et, au niveau affectif et fête, c'est un degré intermédiaire, intermédiaire plus ", à la différence de Grande

Casse :

« Ce sont des vendeurs assez agressifs avec un style de vente pas mal à l'américaine, ce n'est pas un style fêtard du tout : à part une personne, les vendeurs sont tous des mecs qui ont entre quarante et cinquante ans, donc c'est un genre particulier, ce n'est pas la blonde de vingt-cinq ans en minijupe. 》

C'est sur ce plan que la diversité des propriétés et des trajectoires des enquêté e.s intervient dans l'incarnation de la relation marchande. Comédien de formation au parcours atypique, reconverti très tôt dans l'audiovisuel, Yannick, aujourd'hui quinquagénaire et à la tête d'une petite société d'exportation de documentaires, mise sur le jeu (de séduction) lors de ses rendez-vous (c'est même son argument pour me refuser d'y assister) :

« C'est physique ! II y a un périmètre très physique qui est quasi palpable dans la relation. [...] C'est beaucoup de séduction, beaucoup de choses se mettent en place. II y a des gens avec qui il faut rester très distant, il y a des gens qu'il faut toucher... homme, femme... »

\section{Une « civilité marchande»}

Si les enquêté.e.s personnalisent la relation marchande, c'est parce qu'ils et elles se soucient de sa durabilité. Réussir un MIPTV ou un MIF, pour les enquêté e.s, se mesure moins aux contrats signés qu'aux bonnes relations maintenues avec d'autres professionnel·le·s : ce sont des espaces où priment les « dimensions what counts is "partying with the clients." Ecrin's style (hers) is, "not seductive, and as for emotion and partying, we're in the middle, middle to high end," contrary to Grande Casse:

"Their sellers are pretty aggressive, with an American business style, not at all a party-hard style: they are all male bar one, between forty and fifty years old, so it's pretty distinctive, there are no twenty-five-year-old blondes wearing miniskirts."

The diversity of the respondents' attributes and backgrounds is illustrated by how they exemplify their commercial relationships. Yannick, a middle-aged trained actor with an atypical background who converted early into the media domain, is at the head of a small business in documentary exportation. His technique is based on seduction during meetings (this even was the reason for which I was refused entry into his meetings). He explains:

"It gets physical! There's a very physical aspect that's almost palpable. [...] There's a lot of seduction involved, a lot of things are happening. You have to keep a distance with some, but with others you have to be in direct contact [...] men or women."

\section{Commercial Civility}

If the respondents personalize the commercial relationship, it is mainly because they are concerned about how long it might last. Being successful at MIPTV or the MIF is not so much measured in signed contracts as in the number of good relationships one maintains with other professionals: in these spaces, "non-monetary 
non monétaires des transactions " (Menger 2013) et où domine une forme de « civilité marchande » (Pinto 2017 ; Trompette 2009), qui garantit des relations de confiance et même l'installation d'une relation personnalisée entre participant $\cdot e \cdot s$, malgré la distance culturelle et géographique qui les sépare. Ainsi, au lieu « d'exploiter à [leur] avantage le caractère bref et séquentiel des interactions avec des acheteurs mal informés sur la qualité ou sur la distribution de qualité du bien considéré ", les distributeurs entendent « opérer à long terme " sur le marché (Menger 2013). Le pire qui puisse leur arriver est de se fâcher avec un acheteur. Nombre de vendeurs se souviennent ainsi de " ruptures » traumatisantes. Jérémy se rappelle un épisode où deux acheteuses " ont mis la pression", le conduisant à se disputer avec l'une d'elle. Même s'il affirme que c'est « la règle du jeu » et que ces ruptures font partie de la « casse des marchés ", elles constituent des épisodes douloureux aux conséquences durables : «Ça peut s'envenimer, ça peut devenir colérique et ça peut briser des relations pour six mois, un an, deux

ans. »

Timothée se souvient de son côté avoir vendu trop cher son documentaire sur l'Afghanistan à une acheteuse danoise qui refuse désormais de traiter avec lui : « Ça fait dix ans ! Dix ans qu'elle me fait la gueule ! Donc ce n'est pas une bonne politique de profiter de l'actualité parce qu'on sait qu'après les gens ne reviendront pas. ”

Depuis lors, Timothée en a tiré un principe :

"La seule garantie de durée dans ce métier, c'est I'honnêteté : c'est pour ça que je suis contre faire des coups. Demain, même si j'avais les images de Ben Laden en train de se faire tuer, et chaque fois qu'on a des images qui correspondent à quelque chose que les gens veulent, on n'en profite jamais. On ne va jamais leur forcer la main parce qu'ils ne reviendront pas, c'est sûr. C'est la base. transactional dimensions" predominate (Menger 2013), and a type of "commercial civility" prevails (Pinto 2017; Trompette 2009), which guarantees trusting relationships and even establishes a personalized relationship between participants, despite the cultural and geographical distance separating them. Thus, instead of "further exploiting the brief and sequential nature of the interactions with misinformed buyers (to their advantage) regarding the quality or quality of distribution of the goods considered," the distributors intend to "operate over the long term" in the marketplace (Menger 2013). The worst that can happen to them is being on the receiving end of an angry buyer. Several sellers have such memories of traumatic "breakups." Jeremy remembers one moment where two buyers "started piling on the pressure," causing him to argue with one of them. Even if he admits that it is "the name of the game" and these breakups are part of the "market breakdown," they are nonetheless made up of painful episodes with longterm consequences: "Things can deteriorate due to anger, and relationships can break down for six months, even a year or two."

Timothée remembers having sold his documentary on Afghanistan for too high a price to a Danish buyer, who subsequently refused to deal with him: "It's been ten years! Ten years she's been sulking! It's not a good idea to take advantage of hot topics because people don't necessarily come back." Since then, Timothée has learned a lesson:

"The only guarantee of duration in this profession is honesty, which is why I'm against cheap shots. Even if I had images of Bin Laden getting killed in my possession tomorrow. Every time that we have images that correspond to something that people want; we never take advantage of them. We don't force people, because they never come back, that's for sure. That's what it comes down to. That's why I'm 
C'est pour ça que je suis contre les gens qui sont excellents négociateurs parce qu'ils sont extrêmement brillants mais en même temps ils ne se rendent pas compte des dégâts occasionnés. »

Les enquêté.e.s s'accommodent donc très mal des situations de négociation explicite, de mise en concurrence, d'enchères trop longues, qui relèvent pourtant, selon la théorie économique, du fonctionnement attendu d'un marché. Ils et elles savent en effet qu'ils et elles retrouveront ces mêmes partenaires tout au long de leur carrière sur les marchés audiovisuels internationaux. C'est pourquoi « il ne faut pas mentir à un acheteur », selon Mathilde : "Cela fonctionne sur une vraie ancestralité de relations et sur une confiance forte avec les interlocuteurs. " II arrive même à des acheteur.se.s devenu.e.s insolvables de demander le remboursement d'un programme déjà vendu : au MIPTV, en pleine crise grecque, l'acheteuse d'une télévision publique grecque obtien ainsi de Maria, vendeuse chez Denali, l'annulation d'un contrat d'achat pourtant déjà signé sur la série Wallander. D'ailleurs, en cas de tromperie ou d'escroquerie, la réputation d'un professionnel - et avec lui celle de sa société - l'empêche très rapidement de conclure d'autres transactions et il se trouve immédiatement exclu des échanges internationaux : "La réputation va très vite dans le milieu. S'il y a un producteur qui dit : "Lui, le distributeur ne m'a jamais payé", voilà ! », explique Fanny. Jérôme confirme qu'« on connaît les mauvais payeurs ».

Le rôle crucial de la réputation explique que les commérages soient si communs : en "influen[çant] les distributions de l'éloge et du blâme ", ils fabriquent des " classements statutaires » (Elias 1985). Lors d'un rendez-vous au MIF entre Fabiola et Amel, une acheteuse tunisienne, les deux femmes dénoncent plusieurs sociétés françaises qui promettraient de faux prix de vente avant against people who are excellent at negotiating, really smart, but at the same time they don't realize the damage that can be done."

The respondents are not at all accustomed to explicit negotiating and competitive situations, to long bidding, despite the fact that they are expected market behaviours, according to economic theory. They realize that they will come across these same partners throughout their career in the international film and TV marketplaces. This is why "you should never lie to a buyer," according to Mathilde: "everything is based on a real ancestral relationship and strong ties of trust with our intermediaries." Even bankrupt buyers can ask to be reimbursed for a show that has already been sold. At MIPTV, in the middle of the Greek financial crisis, I witnessed a buyer from a Greek television producer obtain a cancellation for a buyer's contract from Maria, a seller at Denali. Even so, in the case of fraud or misconduct, the professionals' reputation-along with the business'-is on the line and can quickly be the cause of a breakdown in future transactions and cause exclusion from international exchanges. Reputations can deteriorate fast in this line of work. If a producer mentions that a distributor "never paid me, that's it!" explains Fanny. Jérôme confirms that everyone "knows the bad payers."

The crucial role of reputations explains why gossip is so widespread: by influencing who is praised and who is blamed, it creates "status ranking" (Elias \& Scotson 1965). During a meeting at the MIF between Fabiola and Amel, a Tunisian buyer, the two women denounce several French businesses who are believed to promised false sales prices before changing them during the contract-signing 
de changer les montants lors de la signature des contrats. Les récits de vols ou d'escroqueries sont effectivement un commérage typique de la sociabilité de marché (Sciardet 1996).

Les salons, foires et marchés internationaux constituent désormais des lieux privilégiés du commerce international. Leur essor étonne dans la mondialisation contemporaine alors que les communications à distance se sont développées et que la régulation et l'institutionnalisation du commerce international sont croissantes. Les explications économiques de ce paradoxe en font des lieux de négociations commerciales, de transactions, voire, dans des travaux plus récents, des lieux d'échanges d'information sur un secteur. Sans nier ces dimensions, l'enquête sur deux marchés internationaux de l'audiovisuel montre qu'y prime une autre dimension pour leurs participant.e.s : l'élaboration d'un entre-soi et la personnalisation des relations marchandes. On fait l'hypothèse que ce constat vaut au-delà des événements internationaux dédiés aux biens culturels, et que les salons, foires et marchés constituent plus généralement une solution originale, dans la mondialisation économique contemporaine, au problème de défiance constitutif du commerce international dans un très grand nombre de secteurs

et d'industries.

De fait, les « marchés » audiovisuels n'en ont que l'appellation puisque les fréquenter sert en premier lieu la formation d'une communauté professionnelle transnationale. Négocier des prix ou s'informer en profondeur sur un secteur économique peut se faire à distance. L'intégration à cette communauté professionnelle se joue, elle, lors de ce type d'événements. C'est en tout cas ce que l'observation des interactions permet de constater au MIF et au MIPTV, notamment lors des rendez-vous commerciaux où il n'est stage. Stories of fraud and misconduct are indeed typical gossip material that constitute the market's sociability (Sciardet 1996).

International trade shows, fairs and marketplaces are therefore privileged spaces of international commerce. Their rise is surprising in the context of contemporary globalization, where long distance communication has developed, and the regulation and institutionalisation of international commerce are increasing. The economic explanations of this paradox in recent studies portray them as spaces for commercial negotiations, transactions, and even information exchange about a specific sector. Without denying these aspects, this survey on two international film and TV marketplaces illustrates that another aspect predominates for their participants: the development of a social grouping and the personalisation of commercial relationships. Our hypothesis is that this observation applies beyond the international events dedicated to cultural goods, and that trade shows, fairs, and marketplaces are on the whole an original solution to the problem of constitutive mistrust in international commerce in the contemporary economic global climate.

In fact, attending these film and TV "marketplaces," which are markets only by name, primarily helps to develop a transnational professional community. Negotiating prices or getting in-depth knowledge on an economic sector can be done at a distance. The process of integrating the professional community is played out in such events. Such observations can be made at the MIF and the MIPTV, especially during commercial meetings where there is no place for discussions of transactions or prices. Regularly 
question ni de transaction ni de prix. La fréquentation régulière de ces marchés est d'ailleurs devenue, à partir des années 1980, une spécialité à part entière : les enquêté·e·s français·es qui ont alors intégré la distribution internationale n'ont jamais cessé de s'y rendre pour retrouver les mêmes interlocuteurs et interlocutrices, tout en changeant de métier, passant des ventes aux achats ou à la coproduction internationale. On comprend alors mieux le sens du « travail émotionnel », de la « disponibilité physique », des « rituels d'initiation ", de la minimisation du registre marchand ou de la civilité de marché qui y règnent. La pérennité et l'enchantement des relations priment sur les « bonnes affaires » : ils en sont même

la condition

Romain Lecler

Université du Québec à Montréal (Uqam) - Département de science politique

\section{Références bibliographiques}

AlexAndRe Olivier (2015). La Règle de l'exception : écologie du cinéma français. Paris, Éditions de l'EHESS.

BATHELt Harald \& Schuldt Nina (2008). « Between Luminaires and Meat Grinders : International Trade Fairs as Temporary Clusters ». Regional Studies, 42(6) : 853-868.

BATHELT Harald \& SChuldt Nina (2010). « International Trade Fairs and Global Buzz, Part I : Ecology of Global Buzz ». European Planning Studies, 18(2) : 1957-1974.

Benjamin Walter (1997) [1982]. Paris, capitale du XIXe siècle : le livre des passages. Traduit en français par Jean Lacoste. Paris, Cerf.

BIELBY Denise (2011). «Staking Claims : Conveying Transnational Cultural Value in a Creative Industry ». American Behavioral Scientist, 55(5) : 525540. attending these markets has become a full-blown speciality in the field since the 1980s: the French individuals interviewed, who are now part of the international distribution industry, never stopped attending and continued to meet the same partners, all the while changing professions, going from sales to purchases or international co-production. We can thus better understand the point of "emotional work," "physical availability," "initiation rituals," the minimized commercial language or the market civility that rule these spaces. The continuity and enchantment of the relationships that take precedence over "good deals" are the very premise of these marketplaces.

Romain Lecler

Université du Québec à Montréal (Uqam) - Département de science politique

\section{References}

AleXANDRE Olivier (2015). La Règle de l'exception: écologie du cinéma français. Paris, Éditions de l'EHESS.

BATHELT Harald \& SCHULDT Nina (2008). "Between Luminaires and Meat Grinders: International Trade Fairs as Temporary Clusters." Regional Studies, 42(6): 853-868.

BATHeLt Harald \& Schuldt Nina (2010). "International Trade Fairs and Global Buzz, Part I: Ecology of Global Buzz." European Planning Studies, 18(2): 1957-1974.

Benjamin Walter (1999) [1982]. The Arcades Project. Translated from German by Kevin McLaughlin and Howard Eiland. Cambridge, Harvard University Press.

BIELBY Denise (2011). "Staking Claims: Conveying Transnational Cultural Value in a Creative Industry." American Behavioral Scientist, 55(5): 525-540. 
Bielby Denise \& HaRRINGton Lee (2008). Global TV : Exporting Television and Culture in the World Market. New York, New York University Press.

BOURDIEU Pierre (2003). «La fabrique de I'habitus économique ». Actes de la recherche en sciences sociales, $150: 79-90$ [https://doi.org/10.3406/ arss.2003.2773].

Brailly Julien \& CoulondRE Alexandre (2016). « Le travail de construction d'une place de marché : centres commerciaux et salons de professionnels ». Revue française de socio-économie, 16 : 161-181.

BRAILLY Julien \& FAVRE Guillaume (2016). « La recette de la mondialisation. Sociologie du travail d'un organisateur de salon ». Sociologie du travail, 58(2) : 138-159.

BurEau of ECONOMic AnAlysis (2013). Survey of Current Business. Washington, BEA.

CARRoll William \& Fennema Meindert (2002). « Is There a Transnational Business Community ? ». International Sociology, 17(3) : 393-419.

CAstells Manuel (1998) [1996]. La Société en réseau : l'ère de l'information. Traduit de l'anglais par Philippe Delamare. Paris, Fayard.

Chantelat Pascal (2002). « La Nouvelle Sociologie Économique et le lien marchand : des relations personnelles à l'impersonnalité des relations ». Revue française de sociologie, 43(3) : 521-556.

Chantelat Pascal \& Vignal Bénédicte (2002). « L'intermédiation du marché de l'occasion. Échange marchand, confiance et interactions sociales ». Sociologie du travail, 44(3) : 315-336.

DEBLUË Claire-Lise (2015). « De l'exposition universelle à la foire nationale. Éléments pour une histoire élargie des expositions durant la Première Guerre mondiale ». Relations internationales, $164: 59-74$.

DJELIC Marie-Laure \& QUACK Sigrid (2010). Transnational Communities. Shaping Global Economic Governance. Cambridge, Cambridge University Press.

Dolbfus Olivier (1982). «Foires et marchés en France ». Espace géographique, 11(1) : 79
BIELBY Denise \& HARRINGTON Lee (2008). Global TV : Exporting Television and Culture in the World Market. New York, New York University Press.

BOURDIEU Pierre (2003). "La fabrique de I'habitus économique.” Actes de la recherche en sciences sociales, 150: 79-90.

Brailly Julien \& CoULONDRE Alexandre (2016). "Le travail de construction d'une place de marché : centres commerciaux et salons de professionnels." Revue française de socio-économie, 16: 161-181.

BRAILLY Julien \& FAVRE Guillaume (2016). "La recette de la mondialisation. Sociologie du travail d'un organisateur de salon." Sociologie du travail, 58(2): 138-159.

Bureau of Economic Analysis (2013). Survey of Current Business. Washington, BEA.

CARROLL William \& FEnNEMA Meindert (2002). "Is There a Transnational Business Community?." International Sociology, 17(3): 393-419.

CAstells Manuel (1996). The Rise of the Network Society. Malden, Mass., Blackwell Publishers.

Chantelat Pascal (2002). "La Nouvelle Sociologie Économique et le lien marchand : des relations personnelles à l'impersonnalité des relations." Revue française de sociologie, 43(3): 521-556.

ChANTELAT Pascal \& Vignal Bénédicte (2002). "L'intermédiation du marché de l'occasion. Échange marchand, confiance et interactions sociales." Sociologie du travail, 44(3): 315-336.

DEBLUË Claire-Lise (2015). "De l'exposition universelle à la foire nationale. Éléments pour une histoire élargie des expositions durant la Première Guerre mondiale." Relations internationales, 164: 59-74.

DJELIC Marie-Laure \& QUACK Sigrid (2010). Transnational Communities. Shaping Global Economic Governance. Cambridge, Cambridge University Press.

Dollfus Olivier (1982). "Foires et marchés en France." Espace géographique, 11(1): 79. 
Dubuisson-Quellier Sophie \& NeuVILLE Jean-Philippe (2003). Juger pour échanger : la construction sociale de l'accord sur la qualité dans une économie des jugements individuels. Paris, Quae.

ELIAS Norbert (1985)[1965]. «Remarques sur le commérage ». Traduit de l'anglais par Francine Muel-Dreyfus. Actes de la recherche en sciences sociales, $60: 23-29$.

ESQUERRE Arnaud (2012). « Jusqu'où le cinéma peut-il être critique ?». Mouvements, $71: 162-179$.

EthIS Emmanuel (2001). Aux marches du palais : le Festival de Cannes sous le regard des sciences sociales. Paris, La Documentation française.

FAVRE Guillaume \& BRAILly Julien (2015). « Salons et définition de normes marchandes : Le cas de la distribution de programmes de télévision en Afrique sub-saharienne ». L'Année sociologique, 65(2) : 425-456.

FONTAINE Laurence (2013). Le Marché. Histoire d'une conquête sociale. Paris, Gallimard.

GARCIA-PARPET Marie-France (2005). « Le Salon des vins de Loire : convivialité et vocation internationale ». Ethnologie française, 35(1) : 6372.

GiMELLO-MeSPLOMB Frédéric \& LATIL Loredana (2003). « Une politique française du cinéma : analyse de la sélection française pour le festival de Cannes ». Protée, 31(2) : 17-28.

GunNING Tom (1994). «The World as Object Lesson : Cinema Audiences, Visual Culture and the St. Louis World's Fair, 1904 ». Film History, 6(4) $422-444$.

Havens Timothy (2006). Global Television Marketplace. Londres, British Film Institute.

HochSCHILD Arlie Russell (1975). « The Sociology of Feeling and Emotion : Selected Possibilities ». Sociological Inquiry, 45(2-3) : 280-307.

HoskINS Colin \& MIRUS Rolf (1988). « Reasons for the US Dominance of the International Trade in Television Programmes ». Media Culture \& Society, 10(4) : 499-515.
Dubuisson-QuelLieR Sophie \& NeUVILLE Jean-Philippe (2003). Juger pour échanger: la construction sociale de l'accord sur la qualité dans une économie des jugements individuels. Paris, Quae.

ELIAS Norbert \& SCOTSON John (1965). The Established and the Outsiders (Chapter 7 "Observations on Gossip"). Londres, Franck Cass and Co.

ESquerRe Arnaud (2012). "Jusqu'où le cinéma peut-il être critique ?." Mouvements, 71: 162-179.

ETHIS Emmanuel (2001). Aux marches du palais: le Festival de Cannes sous le regard des sciences sociales. Paris, La Documentation française.

FAVRE Guillaume \& BraIlLy Julien (2015). "Salons et définition de normes marchandes: le cas de la distribution de programmes de télévision en Afrique sub-saharienne." L’Année sociologique, 65(2): 425-456.

FontAInE Laurence (2013). Le Marché. Histoire d'une conquête sociale. Paris, Gallimard.

GARCIA-PARPET Marie-France (2005). "Le Salon des vins de Loire: convivialité et vocation internationale." Ethnologie française, 35(1): 63-72.

Gimello-Mesplomb Frédéric \& LATIL Loredana (2003). "Une politique française du cinéma: analyse de la sélection française pour le festival de Cannes." Protée, 31(2): 17-28.

GunNING Tom (1994). "The World as Object Lesson: Cinema Audiences, Visual Culture and the St. Louis World's Fair, 1904." Film History, 6(4): 422-444

HAVENS Timothy (2006). Global Television Marketplace. Londres, British Film Institute.

HOCHSCHILD Arlie Russell (1975). "The Sociology of Feeling and Emotion: Selected Possibilities." Sociological Inquiry, 45(2-3): 280-307.

HoskINS Colin \& MIRUS Rolf (1988). "Reasons for the US Dominance of the International Trade in Television Programmes." Media Culture \& Society, 10(4): 499-515. 
JOUVENET Morgan (2001). "Le style du commissaire. Aperçus sur la construction des expositions d'art contemporain 》. Sociétés \& Représentations, 11 : 325-348.

KUIPERS Giselinde (2015). « How National Institutions Mediate the Global Screen Translation, Institutional Interdependencies, and the Production of National Difference in Four European Countries ». American Sociological Review, 80(5) : 985-1013.

LE VeLLy Ronan (2007). « Les démonstrateurs de foires ». Ethnologie française, 37(1) : 143-151.

LECLER Romain (2013). Sociologie de la mondialisation. Paris, La Découverte, «Repères ».

LECLER Romain (2015). « Nouvelles vagues. Cannes, la fabrique française d'un universel cinématographique ». Actes de la recherche en sciences sociales, 206-207 : 14-33

LECLER Romain (2017a). «La montée des marchés à Cannes. Le circuit des échanges audiovisuels internationaux, sa chronologie et ses trajets professionnels ». Réseaux, $200: 209-242$.

LECLER Romain (2017b). « La grille et la palme. Deux régimes d'exportation des biens audiovisuels ». Revue française de socio-économie, $19: 153$ 175 .

LECLER Romain (2018). « Mondialisation ». In SMITH Andy \& SMITH Colin (dir.), Dictionnaire d'économie politique. Paris, Presses de Sciences-Po : 307-318.

Lemercier Claire, Bartolomel Arnaud, Marzagall Sylvia (2012). « Les commis voyageurs, acteurs et témoins de la grande transformation ». Entreprises et histoire, $66: 7-21$.

LEMERCIER Claire \& SGARD Jérôme (2015). Arbitrage privé international et globalisation(s). Mission de recherche Droit et Justice, CNRS, SciencesPo.

Margairaz Dominique (1988). Foires et marchés dans la France préindustrielle. Paris, Éditions de l'EHESS.
JOUVENET Morgan (2001). "Le style du commissaire. Aperçus sur la construction des expositions d'art contemporain." Sociétés \& Représentations, 11: 325-348.

KUIPERS Giselinde (2015). "How National Institutions Mediate the Global: Screen Translation, Institutional Interdependencies, and the Production of National Difference in Four European Countries." American Sociological Review, 80(5): 985-1013.

LE VeLLy Ronan (2007). "Les démonstrateurs de foires." Ethnologie française, 37(1): 143-151.

LECLER Romain (2015) [2013]. Sociology of Globalization. Calcutta, Sampark.

LECLER Romain (2015). "Nouvelles vagues. Cannes, la fabrique française d'un universel cinématographique." Actes de la recherche en sciences sociales, 206-207: 14-33.

LECLER Romain (2017a). "La montée des marchés à Cannes. Le circuit des échanges audiovisuels internationaux, sa chronologie et ses trajets professionnels." Réseaux, 200: 209-242.

LECLER Romain (2017b). "La grille et la palme. Deux régimes d'exportation des biens audiovisuels." Revue française de socio-économie, 19: 153175.

LECLER Romain (2018). "Mondialisation." In SMith Andy \& SMITH Colin (dir.), Dictionnaire d'économie politique. Paris, Presses de Sciences-Po: 307-318.

Lemercier Claire, Bartolomel Arnaud, Marzagalli Sylvia (2012). "Les commis voyageurs, acteurs et témoins de la grande transformation." Entreprises et histoire, 66: 7-21.

LEMERCIER Claire \& SGARD Jérôme (2015). Arbitrage privé international et globalisation(s). Mission de recherche Droit et Justice, CNRS, SciencesPo.

MARGAIRAZ Dominique (1988). Foires et marchés dans la France préindustrielle. Paris, Éditions de l'EHESS. 
MARTIN David (2002). «Dispositifs de défiance et fluidité des échanges sur les marchés financiers de gré à gré ». Sociologie du travail, 44 :55-74.

MASKELL Peter (2014). «Accessing Remote Knowledge - the Roles of Trade Fairs, Pipelines, Crowdsourcing and Listening Posts ». Journal of Economic Geography, 14(5) : 883-902.

Menger Pierre-Michel (2013). «Valeurs incertaines, marchés aux puces, ventes en ligne : comment s'assurer de la qualité ? ». Communication, $93: 147-172$.

MiLLER Toby (2001). Global Hollywood. Londres, British Film Institute.

Moeran Brian \& Strandgaard Pedersen Jesper (2011). Negotiating Values in the Creative Industries: Fairs, Festivals and Competitive Events. Cambridge, New York, Cambridge University Press.

Moran Albert (2009). New Flows in Global TV. Chicago, University of Chicago Press.

MORGAN Glenn (2001). "Transnational Communities and Business Systems », Global Networks, 1(2) : 113-130.

Organisation mondiale du Commerce/World Trade Organization (2015). Statistiques du commerce international 2015. Genève, OMC.

PINTO Louis (2017). " La civilité marchande. Agressivité et retenue professionnelles dans les activités de vente ». Actes de la Recherche en Sciences Sociales, 216-217 : 24-41.

Rinallo Diego \& GolfEtTo Francesca (2011). « Exploring the Knowledge Strategies of Temporary Cluster Organizers : A Longitudinal Study of the EU Fabric Industry Trade Shows (1986-2006) ». Economic Geography, 87(4) : 453-476.

Roux Xavier (2009). « Les professionnels de la vente dans les banques : conseillers en vitrine, commerciaux en coulisses ? ». In GADÉA Charles \& DemaziÈRE Didier (dir.), Sociologie des groupes professionnels. Acquis récents et nouveaux défis. Paris, La Découverte : 310-320.
MARTIN David (2002). "Dispositifs de défiance et fluidité des échanges sur les marchés financiers de gré à gré." Sociologie du travail, 44: 55-74.

MASKELL Peter (2014). "Accessing remote knowledge - the roles of trade fairs, pipelines, crowdsourcing and listening posts." Journal of Economic Geography, 14(5): 883-902.

MEnger Pierre-Michel (2013). "Valeurs incertaines, marchés aux puces, ventes en ligne: comment s'assurer de la qualité ?." Communication, 93 147-172.

MILLER Toby (2001). Global Hollywood. Londres, British Film Institute.

Moeran Brian \& Strandgaard Pedersen Jesper (2011). Negotiating Values in the Creative Industries: Fairs, Festivals and Competitive Events. Cambridge, New York, Cambridge University Press.

Moran Albert (2009). New Flows in Global TV. Chicago, University of Chicago Press.

MoRgan Glenn (2001). "Transnational Communities and Business Systems," Global Networks, 1(2): 113-130.

Organisation mondiale du Commerce/World Trade Organization (2015). Statistiques du commerce international 2015. Genève, OMC

PINTO Louis (2017). "La civilité marchande. Agressivité et retenue professionnelles dans les activités de vente." Actes de la Recherche en Sciences Sociales, 216-217: 24-41.

RinAllo Diego \& Golfetto Francesca (2011). "Exploring the Knowledge Strategies of Temporary Cluster Organizers: A Longitudinal Study of the EU Fabric Industry Trade Shows (1986-2006)." Economic Geography, 87(4): 453-476.

Roux Xavier (2009). "Les professionnels de la vente dans les banques: conseillers en vitrine, commerciaux en coulisses ?." In GADÉA Charles \& DemAZIÈRE Didier (eds.), Sociologie des groupes professionnels. Acquis récents et nouveaux défis. Paris, La Découverte: 310-320. 
SASSEN Saskia (1996) [1991]. La Ville globale : New York, Londres, Tokyo. Traduit de l'anglais par Denis-Armand Canal. Paris, Descartes.

SCHULDT Nina \& BATHELT Harald (2011). "International Trade Fairs and Global Buzz. Part II : Practices of Global Buzz », European Planning Studies, 19(1) : 1-22.

SCIARDET Hervé (1996). "Commerce, marchés, transactions : une approche ethnographique ». Genèses, $25: 29-49$.

SHARLAND Alex \& BALOGH Peter (1996). «The Value of Nonselling Activities at International Trade Shows ». Industrial Marketing Management, 25(1) 59-66.

Skov Lise (2006). " The Role of Trade Fairs in the Global Fashion Business ». Current Sociology, 54(5) : 764-783.

SteEmers Jeanette (2008). Selling Television : British Television in the Global Marketplace. Londres, British Film Institute.

SURUBARU Alina (2013). " Les producteurs roumains de l'habillement à la recherche de clients : une analyse sociologique des rencontres d'affaires ». Sociologie du travail, 54 : 457-474.

TrivelLato Francesca (2016) [2012]. Corail contre diamants. Réseaux marchands, diaspora sépharade et commerce lointain (de la Méditerranée à l'océan Indien, XVIII' siècle. Traduit de l'anglais par Guillaume Calafat. Paris, Seuil.

TROMPETTE Pascale (2009). " Les conseillers funéraires : du tact civil aux tactiques commerciales 》. In GADÉA Charles \& DemaZlèRe Didier (dir.), Sociologie des groupes professionnels. Acquis récents et nouveaux défis. Paris, La Découverte : 299-309.

VALCK Marijke (DE) (2007). Film Festivals : From European Geopolitics to Global Cinephilia. Amsterdam, Amsterdam University Press.

WEBERAnne-Katrin (2015). «L'exposition de la télévision dans l'entre-deuxguerres : entre appropriations nationales et échanges transnationaux ». Relations internationales, $164:$ 75-92.
SASSEN Saskia (1991). The Global City: New York, London, Tokyo. Princeton, Princeton University Press.

SCHULDT Nina \& BAthelt Harald (2011). "International Trade Fairs and Global Buzz. Part II: Practices of Global Buzz," European Planning Studies, 19(1): 1-22.

SCIARDET Hervé (1996). "Commerce, marchés, transactions: une approche ethnographique." Genèses, 25: 29-49.

Sharland Alex \& Balogh Peter (1996). "The Value of Nonselling Activities at International Trade Shows." Industrial Marketing Management, 25(1): 59-66.

Skov Lise (2006). "The Role of Trade Fairs in the Global Fashion Business." Current Sociology, 54(5): 764-783.

STEEMERS Jeanette (2008). Selling Television: British Television in the Global Marketplace. Londres, British Film Institute.

SURUBARU Alina (2013). "Les producteurs roumains de l'habillement à la recherche de clients : une analyse sociologique des rencontres d'affaires." Sociologie du travail, 54: 457-474.

TrivelLato Francesca (2012). The Familiarity of Strangers: The Sephardic Diaspora, Livorno, and Cross-Cultural Trade in the Early Modern Period. New Haven, Yale University Press.

TROMPETTE Pascale (2009). "Les conseillers funéraires: du tact civil aux tactiques commerciales." In GADÉA Charles \& Demazière Didier (eds.), Sociologie des groupes professionnels. Acquis récents et nouveaux défis. Paris, La Découverte: 299-309.

VALCK Marijke (DE) (2007). Film Festivals: From European Geopolitics to Global Cinephilia. Amsterdam, Amsterdam University Press.

Weber Anne-Katrin (2015). "L'exposition de la télévision dans l'entre-deuxguerres : entre appropriations nationales et échanges transnationaux." Relations internationales, 164: 75-92. 
WEBER Florence (2000). «Transactions marchandes, échanges rituels, relations personnelles. Une ethnographie économique après le Grand Partage ». Genèses, $41:$ 85-107.

Zelizer Viviana (2007) [2005]. The Purchase of Intimacy. Princeton, Princeton University Press.
WEBER Florence (2000). "Transactions marchandes, échanges rituels, relations personnelles. Une ethnographie économique après le Grand Partage." Genèses, 41: 85-107.

Zelizer Viviana (2007) [2005]. The Purchase of Intimacy. Princeton, Princeton University Press. 